\title{
Specialized Subpopulations of Deep-Layer Pyramidal Neurons in the Neocortex: Bridging Cellular Properties to Functional Consequences
}

\author{
[DArielle Baker, ${ }^{1}$ Brian Kalmbach, ${ }^{2,3}$ Mieko Morishima, ${ }^{4}$ Juhyun Kim, ${ }^{5}{ }^{\circledR}$ Ashley Juavinett, ${ }^{6}$ Nuo Li, ${ }^{7}$ \\ and Nikolai Dembrow ${ }^{3,8}$ \\ ${ }^{1}$ Department of Molecular and Systems Biology, Geisel School of Medicine at Dartmouth College, Hanover, New Hampshire 03755, ${ }^{2}$ Allen Institute for Brain \\ Science, Seattle, Washington 98109, ${ }^{3}$ Department of Physiology and Biophysics, University of Washington, Seattle, Washington 98195 , ${ }^{4}$ National Institute \\ for Physiological Sciences, Graduate University for Advanced Studies, Okazaki, Japan, 444-8787, ${ }^{5}$ Solomon H. Snyder Department of Neuroscience, Johns \\ Hopkins University School of Medicine, Baltimore, Maryland 21205, ${ }^{6}$ Cold Spring Harbor Laboratory, Cold Spring Harbor, New York $11724,{ }^{7}$ Baylor College \\ of Medicine, Houston, Texas 77030, and ${ }^{8}$ Epilepsy Center of Excellence, Department of Veterans Affairs Medical Center, Seattle, Washington 98108
}

Neocortical pyramidal neurons with somata in layers 5 and 6 are among the most visually striking and enigmatic neurons in the brain. These deep-layer pyramidal neurons (DLPNs) integrate a plethora of cortical and extracortical synaptic inputs along their impressive dendritic arbors. The pattern of cortical output to both local and long-distance targets is sculpted by the unique physiological properties of specific DLPN subpopulations. Here we revisit two broad DLPN subpopulations: those that send their axons within the telencephalon (intratelencephalic neurons) and those that project to additional target areas outside the telencephalon (extratelencephalic neurons). While neuroscientists across many subdisciplines have characterized the intrinsic and synaptic physiological properties of DLPN subpopulations, our increasing ability to selectively target and manipulate these output neuron subtypes advances our understanding of their distinct functional contributions. This Viewpoints article summarizes our current knowledge about DLPNs and highlights recent work elucidating the functional differences between DLPN subpopulations.

\section{Introduction}

The mammalian six-layered neocortical microcircuit continues to present a tantalizing puzzle for neuroscientists: how does this elegant structure, with diverse neuron subtypes and complex connectivity, perform the computations underlying the sensory, motor, and cognitive tasks that animals achieve seemingly effortlessly? Unraveling the biological principles that govern these microcircuits will lay the foundation for understanding cortical function. Given the complexity of the multitude of afferent inputs to cell types across all cortical layers, a useful approach is to focus on the relatively fewer cortical projection neuron subclasses that generate the bulk of cortical output.

Infragranular, or deep-layer, pyramidal neurons (DLPNs), are found in layer 5 (L5) and layer 6 (L6) of the neocortex and are

\footnotetext{
Received March 9, 2018; revised May 9, 2018; accepted May 11, 2018.

Author contributions: A.B. and N.D. designed research; A.B., B.K., M.M., J.K., A.J., N.L. and N.D. wrote the paper. This work was supported by National Institutes of Health Grant NS044163 and VA-BLR\&D Merit Review 821MRNB-24218 to N.D., Japan Society for the Promotion of Science KAKENHI 15KT0013 to M.M., and Simons Collaboration on the Global Brain to A.J. N.L. was supported by the McNair Foundation, Whitehall Foundation, Sloan Foundation, National Institutes of Health Grant NS104781, and Searle Scholars Program. J.K. was supported by the National Institutes of Health Grant NS085121 and Target ALS. We thank Solange Brown, Allan Gulledge, Rebecca Hodge, and William Spain for discussions. B.K. thanks Allen Institute founder Paul G. Allen, for his vision, encouragement, and support.

The authors declare no competing financial interests.

Correspondence should be addressed to Dr. Nikolai Dembrow, Department of Physiology and Biophysics, University of Washington, Seattle, WA 98195. E-mail: ndembrow@uw.edu.

DOI:10.1523/JNEUROSCI.0150-18.2018

Copyright $@ 2018$ the authors $\quad 0270-6474 / 18 / 385441-15 \$ 15.00 / 0$
}

a major source of output from the neocortex. Afferent fibers from many different brain regions provide input signals that are integrated and processed across layers, and then sent to disparate areas via DLPNs. Ongoing research is unveiling key genetic, morphological, hodological, and functional differences between these extensively interconnected and electrophysiologically complex DLPNs.

Broadly, DLPNs can be divided into two categories based on their axonal projections: those with long-range projections confined to the telencephelon (intratelencephalic [IT]) and those that additionally project to other brain regions (extratelencephalic [ET]; Fig. 1) (Reiner et al., 2003; Molnár and Cheung, 2006; Shepherd, 2013; Saiki et al., 2018). It is important to note that, whereas IT neurons are restricted to the telencephalon, ET neurons project both within the telencephalon and beyond. ET and IT populations can be further subdivided by their specific projection targets and/or by the primary paths along which their axons project. For example, some ET neurons are termed pyramidal tract (PT) neurons based on their projection along the white matter tracts in the brainstem. PT neurons innervate a variety of targets both within and outside of the telencephalon, including the spinal cord, pons, striatum, brainstem, and/or thalamus (Hirai et al., 2012; Kita and Kita, 2012; Ueta et al., 2014; Rojas-Piloni et al., 2017). Individual L5 PT neurons contact multiple telencephalic and subcortical targets (Guo et al., 2017a).

Another particularly diverse subset of ET neurons located in L6 are termed corticothalamic (CT) neurons because of their 


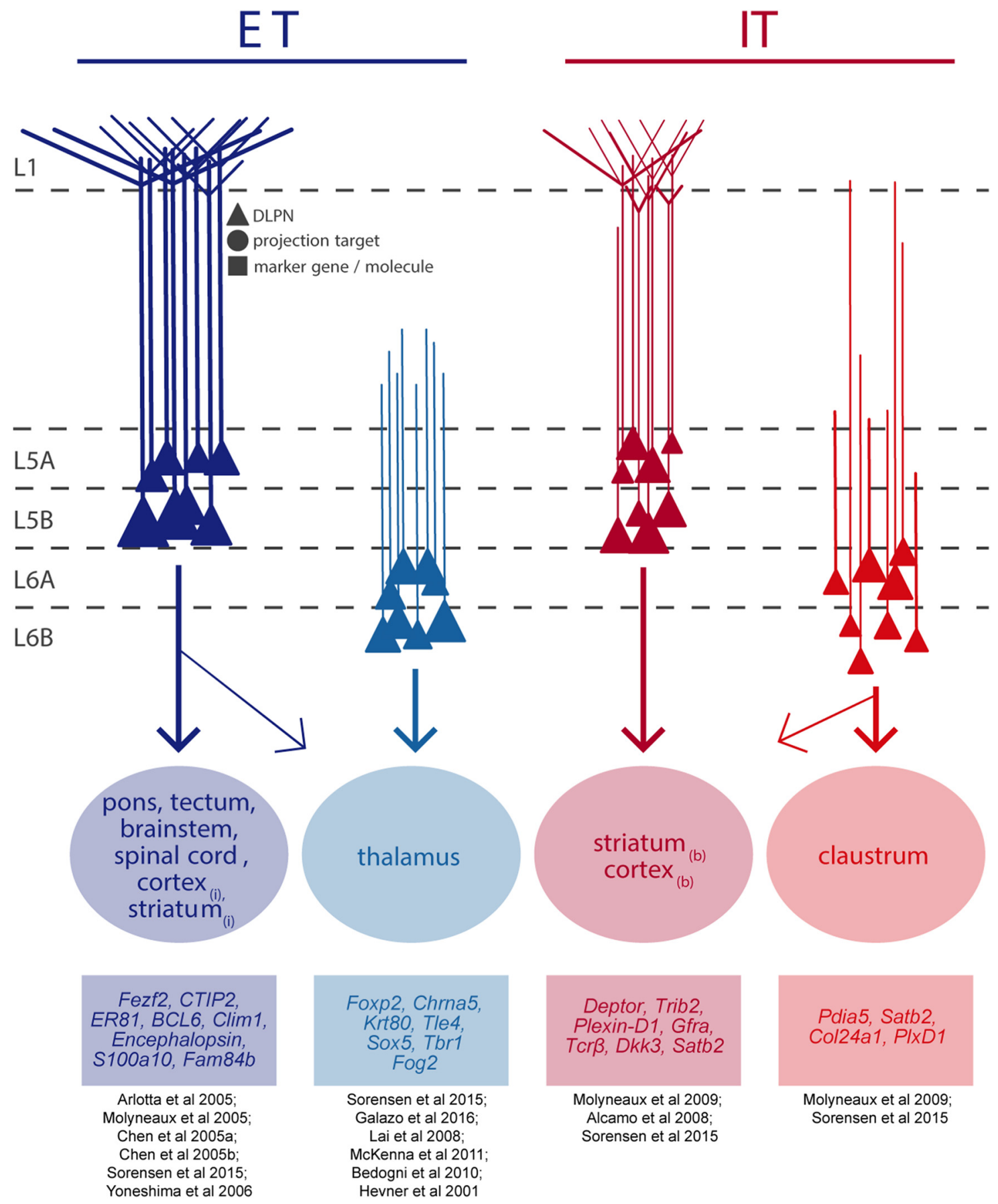

Figure 1. Diversity in characteristic properties of DLPNs in rodent cortex. Whereas ET (blue) and IT (red) projection neurons are found throughout the infragranular layers, distinct subtypes of these projection neurons are found in L5 versus L6. Subtypes of ET and IT projection neurons display diversity in sublaminar localization, dendritic morphology, long-range projection target, and characteristic gene expression. Different DLPN types are characterized by a particular apical dendritic morphology or sublaminar somatic position, but there is extensive variability in these features within each class of DLPNs. For example, L5 IT neurons can possess extensive apical tufts or can be tuftless. Also shown here are the brain regions to which each DLPN sends long-range axonal projections; these projections can be ipsilateral (i), contralateral (c), or bilateral (b). However, not all neurons belonging to a DLPN type project to each brain region listed. For example, single L5 ETs may project to only a couple of the brain regions listed. Finally, a few of potentially many characteristic molecular markers of each DLPN type are listed (Voelker et al., 2004; Arlotta et al., 2005; Yoneshima et al., 2006; Molyneaux et al., 2009; Fame et al., 2011; Costa and Müller, 2014; Sorensen et al., 2015). Notably, not every neuron belonging to a DLPN type expresses each gene, and there is substantial overlap in the expression of these molecular markers between DLPN subtypes.

projections to thalamus (Bourassa and Deschênes, 1995; Zhang and Deschênes, 1997; Briggs and Usrey, 2008; Ueta et al., 2013; Zurita et al., 2017; Chevée et al., 2018; Hasse et al., 2018). L6 CT neurons are comprised of several distinct subpopulations with disparate sublaminar distributions (see below) that project to primary sensory thalamus, higher-order thalamic nuclei, or both (Lévesque et al., 1996; Zhang and Deschênes, 1997;
Thomson, 2010; Shima et al., 2016; Chevée et al., 2018). The extent to which different L6 CT neuron subpopulations target multiple regions remains less clear, although recent work suggests that some L6 CT neuron subpopulations project to distant cortical areas, including contralateral cortex, whereas others do not (Shima et al., 2016; Guo et al., 2017a; HoerderSuabedissen et al., 2018). 
Similar diversity exists within IT neuron subpopulations. The projections of some IT neuron populations are restricted to the cortical region in which they reside; some project to the claustrum and ipsilateral striatum, whereas others project across the corpus callosum to contralateral cortex (termed commissural or corticocortical, respectively) and/or to the contralateral striatum (Fig. 1) (Wilson, 1987; Lévesque et al., 1996; Otsuka and Kawaguchi, 2011; Shepherd, 2013; E. J. Kim et al., 2015). In some cases, it remains necessary to confirm that each specific IT neuron subpopulation's long-range projections are indeed restricted to the telencephalon. For many populations the full complement of possible ET targets may not have yet been excluded with retrograde tracers, and single-axon tract tracing studies are also lacking. Labeling cell populations in conjunction with detailed tract tracing (e.g., http://ml-neuronbrowser.janelia.org/) will prove invaluable in future studies. Continued efforts to characterize the highly specific organization of both ET and IT populations will enhance our current understanding of cortical circuits.

ET and IT neurons are molecularly distinct and maintain their unique intrinsic and synaptic properties into adulthood. While our understanding of these distinctions has expanded significantly over the last decade, disparate studies across multiple species and cortical areas highlight the need to synthesize our understanding of these populations. Moreover, recent advances in our ability to selectively target and manipulate these subpopulations in rodents have enabled more precise dissection of the distinct roles of deep-layer cortical neurons within the greater cortical microcircuit.

Here, we explore emerging evidence that further delineates these subpopulations, and we hypothesize how cellular physiology and synaptic connectivity inform circuit function across cortices. Additionally, we review the exciting functional consequences recently attributed to these subpopulations, connecting the physiology of DLPN subtypes to their functional differences observed in vivo. Finally, while the majority of recent work is derived from rodent models, we highlight cases in which comparisons can be made with findings in nonhuman primates.

\section{Molecular hallmarks distinguishing DLPNs}

The neocortex develops via a stereotyped "inside/out" pattern of development, with deep layers emerging first and superficial layers last (Angevine and Sidman, 1961; Rakic, 1974; Molyneaux et al., 2007). Radial migration toward the pial surface dictates that excitatory cells residing in the same layer share similar birth dates; for example, in mouse, L6 callosal- and thalamic-projecting neurons are born at embryonic day $\sim 12.5$, whereas L5 IT and ET neurons are born at embryonic day $\sim 13.5$ (McConnell, 1991). DLPNs and interneurons originate from pools of progenitors in the dorsal ventricular/subventricular zones and the ganglionic eminences, respectively (Gal et al., 2006; Kawaguchi et al., 2008; Leone et al., 2008; Kowalczyk et al., 2009; Lodato et al., 2015; Vasistha et al., 2015). Despite sharing a common developmental origin, DLPNs display remarkable diversity in molecular and gene expression, which may provide insight regarding the mechanisms that govern their development, as well as tools to selectively target DLPNs subpopulations.

\section{Gene expression and projection-type specification}

Differences in gene expression between DLPNs emerge in embryonic development and mediate the specification of projection targets (Molyneaux et al., 2007; Lodato et al., 2015). Several transcription factors determine projection type, with L5 ET neurons being the best molecularly characterized infragranular subtype in this regard. Fezf2 (also known as Fezl) and CTIP2 (also known as $B c l 11 b$ ) are required for the generation of L5 corticospinal neurons; in the absence of these genes, corticospinal neurons fail to emerge, and the expression of marker genes for DLPNs is altered (Leid et al., 2004; Arlotta et al., 2005; Chen et al., 2005; Molyneaux et al., 2005). Ectopic Fezf2 expression in upper layer neurons causes supragranular neurons to express L5 corticospinal cellular properties, including long-range subcortical projections (Chen et al., 2005; De la Rossa et al., 2013; Ye et al., 2015).

Specification of different DLPN types is driven by several reciprocally repressive transcription factors. Fezf2 and CTIP2 promote L5 ET fate by suppressing transcription factors associated with L6 ETs (McKenna et al., 2011; Srinivasan et al., 2012; Cánovas et al., 2015). Conversely, transcription factors, such as SOX5 and Tbr1, foster L6 ET fate through the suppression of L5 ETrelated transcription factors (Hevner et al., 2001; Lai et al., 2008; Bedogni et al., 2010; McKenna et al., 2011). Similarly, transcription factors that encourage the specification of L5 and L6 IT neurons do so through the inhibition of ET-related transcription factors (Alcamo et al., 2008; Britanova et al., 2008; Leone et al., 2008, 2015; Muralidharan et al., 2017).

For several transcription factors and marker genes that display projection-type specificity (Fig. 1), how these elements interact or contribute to specific phenotypes is unclear. Many reported marker genes are transiently active during development (Arlotta et al., 2005; Leone et al., 2015; Lodato et al., 2015), making it difficult to distinguish whether a particular expression pattern persists into adulthood or is restricted to a particular type of neuron in the adult brain. For example, Fezf2, which is restricted to PT neurons in developing brain, is expressed in a subtype of L5 IT neuron in the adult brain (Tantirigama et al., 2014, 2016). Furthermore, transient Satb2 expression early in cortical development is required for normal corticospinal tract formation (Leone et al., 2015; McKenna et al., 2015). Interestingly, the expression of specific subsets of genes and long-range projection targets covary (Molyneaux et al., 2009; Sorensen et al., 2015; Chevée et al., 2018). Thus, for both IT and PT neurons, the specific pattern of long-range projections appears to be genetically specified.

These observations raise questions about how many subtypes of projection neuron exist in the adult brain. Do they share common gene expression patterns, and are these subtypes found ubiquitously throughout different cortical areas? One fruitful approach to resolving this problem has been to examine the gene expression profiles from subpopulations of cortical neurons labeled in transgenic mouse lines and/or retrograde tracer injections (Sugino et al., 2006; Doyle et al., 2008; Zeisel et al., 2015; Shima et al., 2016; Tasic et al., 2016; Chevée et al., 2018). These approaches have revealed a heretofore unappreciated variety of cell types in infragranular cortex. A recent study in mouse primary visual cortex reports that L5 and L6 possess at least eight and six transcriptomically unique types of glutamatergic neurons, respectively (Tasic et al., 2016). While the number of unique pyramidal cell types remains a subject of debate, several studies indicate the existence of multiple subtypes of DLPNs. Consistent with this hypothesis, in situ hybridization reveals combinatorial gene-expression profiles that label different populations of IT and ET neurons (Molyneaux et al., 2009; Sorensen et al., 2015). Interestingly, DLPNs display a significant amount of interareal genetic variability (Sugino et al., 2006), presenting the possibility that distinct IT and ET subpopulations are present in different cortical areas. Furthermore, transcriptomically defined subtypes of DLPNs exhibit distinct patterns of long-range 
Table 1. Mouse lines used to target DLPNs ${ }^{a}$

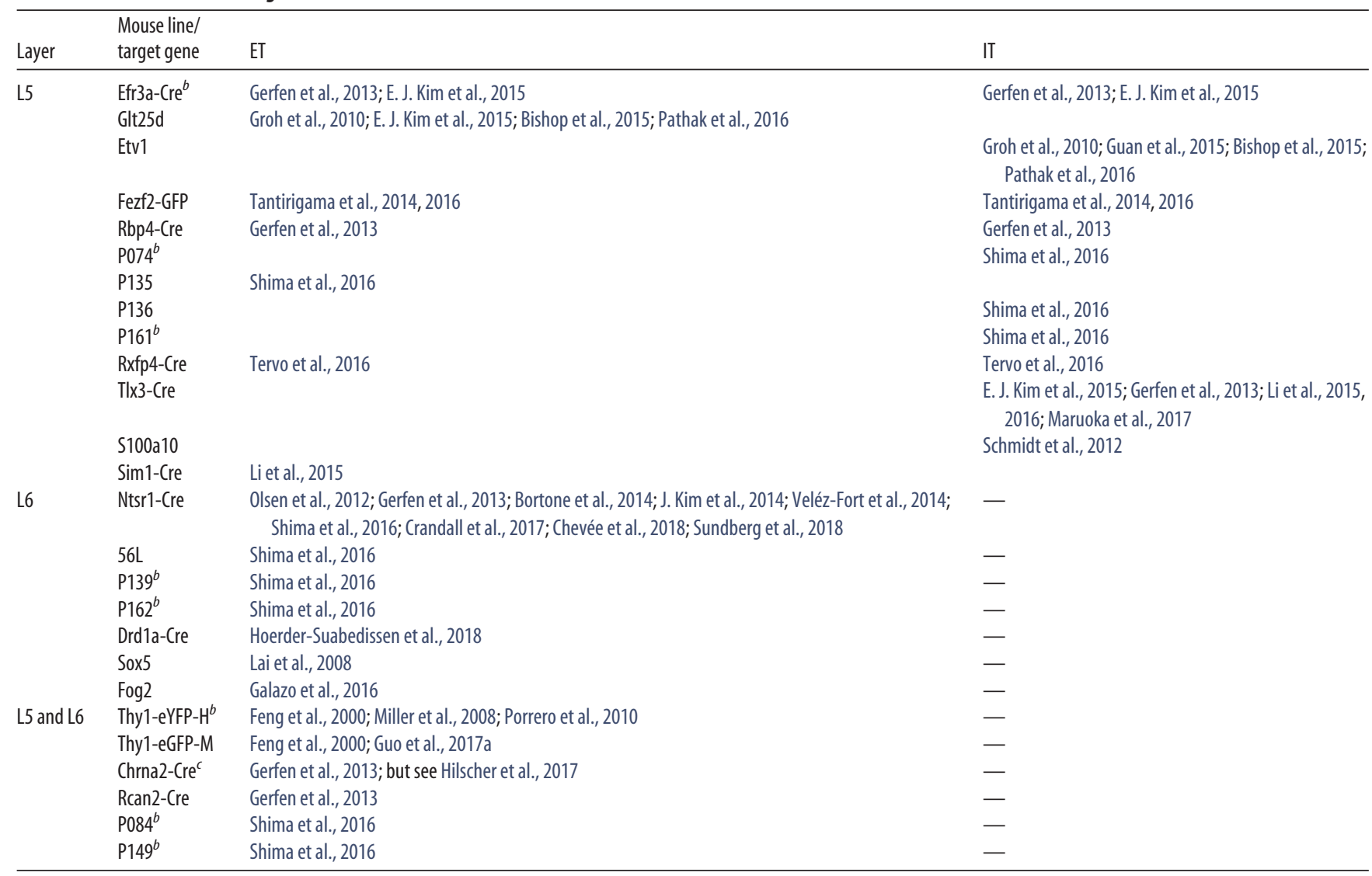

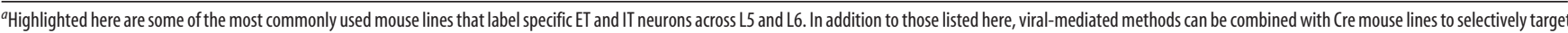
subpopulations.

${ }^{b}$ Dependent upon brain region.

'Dependent upon particular line.

projections (Chevée et al., 2018). Thus, there appears to be correspondence between transcriptomically defined cell types and the diversity of axonal projections reported in classes of DLPN (Fig. 1).

Experimental targeting of genetically distinct DLPNs The molecular diversity in DLPNs provides a genetic basis for selectively targeting them. To this end, many mouse lines that label specific DLPN subtypes have been developed, some of which are listed in Table 1 (Gong et al., 2007; Gerfen et al., 2013; Harris et al., 2014; Shima et al., 2016). Additionally, Cre lines that label multiple populations of DLPNs (e.g., Rbp4-Cre) can be used together with AAV serotypes that retrogradely infect axons to retrogradely label ET and IT populations (Tervo et al., 2016).

Important caveats should be kept in mind when using this approach to target neuronal subpopulations. First, different lines targeting the same gene/transcription factor may not necessarily label the same population. For example, the Thy1-eYFP-H BACcre line labels a subset of ET neurons, the Thy1-eGFP-M line both L5 PT and a subtype of L6 CT neurons, whereas the Thy1eYFP-16 line labels both superficial and deep layer PNs (Feng et al., 2000; Miller et al., 2008; Porrero et al., 2010; Guo et al., 2017a). One BAC-cre line targeting the nicotinic acetylcholine receptor a2 subunit labels ET neurons (Gerfen et al., 2013), whereas other lines label interneuron populations (Hilscher et al., 2017). For many mouse lines, it is necessary to confirm that they label the same DLPN population in different cortical regions, as expression may be area-specific (e.g., Porrero et al., 2010). In the
Efr3a-Cre line, PT neurons are labeled in extrastriate visual areas and a near-projecting IT neuron subtype in V1 (Gerfen et al., 2013; E. J. Kim et al., 2015). Finally, it is difficult to know how completely each targeted DLPN population is labeled within each subregion for different mouse lines. The neurotensin receptor 1 (Ntsr1), a genetic marker that labels a subset of L6 CT neurons that project to primary thalamic nuclei, is commonly used for its robust labeling within sensory cortices, but only sparsely labels mPFC (Harris et al., 2014). Furthermore, not all L6 CT neurons in sensory cortex are labeled by the Ntsr1 line (Shima et al., 2016); and although $\mathrm{Ntsr1}^{+}$neurons do not project to contralateral cortex (Gerfen et al., 2013), there is evidence of L6 CT neurons whose projections within thalamus are exclusively to higherorder regions also send projections to contralateral cortex (Shima et al., 2016; Hoerder-Suabedissen et al., 2018).

Several novel tools are emerging that will improve researchers' ability to selectively target neuronal subpopulations (Luo et al., 2018). One approach has been to target elements that control the expression of the transcription factors driving DLPNs' identity. Transgenic mouse lines can be further refined using enhancer trapping with lentiviral (Shima et al., 2016) or CRISPR/Cas9 (Lopes et al., 2016) strategies. Mapping the unique chromatin accessibility of different neuronal subpopulations may be a potential tool for teasing apart subpopulations within more broadly expressing Cre lines (Gray et al., 2017). Another exciting avenue in identifying neuronal subpopulations is the ability to selectively insert unique genetic "barcodes" into individual neurons and 
map out their projection targets (Kebschull et al., 2016; Han et al., 2018; Rosenberg et al., 2018). Finally, combining in utero electroporation, a useful experimental strategy of targeting region- or laminar-specific neuronal subpopulations (Adesnik and Scanziani, 2010; Bitzenhofer et al., 2017), and genetic approaches may help to further identify subpopulations.

\section{Cross-species differences in gene expression}

One further challenge is addressing whether the molecular hallmarks of particular projection types in the mouse are shared in other species. There are temporal and spatial differences in the expression of many genes between rodent and primate brain (Zeng et al., 2012; Bakken et al., 2017; Fame et al., 2017); thus, significant differences in marker genes for a particular projection type are expected between species (for common deep layer genes in mouse vs human, see Hevner, 2007). Additionally, specific morphologically defined cell types (e.g., von Economo neurons, fork cells) in primate cortex have not been found in rodent cortex (von Economo and Koskinas, 2007; Seeley et al., 2012). Although it is uncertain where these cell types fit in the broad classification scheme, gene-expression profiles may be useful in correlating cross-species subpopulations. For example, von Economo neurons express both Fezf2 and CTIP2, suggesting that they may represent a specialized L5 ET type (Cobos and Seeley, 2015). These issues highlight the paramount need for further development of genetically targeted tools to enable continued investigation of cell types and circuits across different species.

\section{Cellular properties of DLPNs}

Classically, DLPNs were distinguished by their sublaminar location (e.g., L5A vs L5B: Ito, 1992; Manns et al., 2004), dendritic morphology (thick-tufted vs thin-tufted: Wise and Jones, 1977), and/or firing pattern (regular spiking, intrinsically bursting, fastadapting: Connors et al., 1982; Spain et al., 1991). While many of these properties were linked to different DLPN projection targets early in their characterization (e.g., Mason and Larkman, 1990; Z. Wang and McCormick, 1993), they are worth revisiting in the context of more recent studies.

\section{Laminar segregation}

The laminar segregation of projection neurons depends upon cortical region and neuron subtype (Fig. 1). Within L5, the somata of IT and most ET neuron populations are distributed through both L5A and L5B (Anderson et al., 2010; Dembrow et al., 2010; Groh et al., 2010; Mao et al., 2011; Morishima et al., 2011; Oswald et al., 2013; Ueta et al., 2014; Tantirigama et al., 2016; Rojas-Piloni et al., 2017). However, one exceptional subtype of ET neuron is restricted to L5B: the corticospinal neuron (Nudo and Masterton, 1990; Li and Waters, 1991; Anderson et al., 2010; Oswald et al., 2013; Suter et al., 2013; but see Ueta et al., 2014; Suter and Shepherd, 2015). While sublaminar segregation does not separate IT from ET subtypes, it may be used to distinguish particular L5 ET subpopulations that project to the brainstem or the thalamus (Hattox and Nelson, 2007; Rojas-Piloni et al., 2017). Sublaminar segregation depends upon the cortical region (Groh et al., 2010), perhaps in part due to the fact that the size of each sublayer expands and contracts across different cortical regions (DeFelipe et al., 2002; Kubota et al., 2007; Shepherd, 2009).

Similar to L5, both IT and ET neurons' somata are found throughout L6 (Fig. 1) (Kumar and Ohana, 2008; Mao et al., 2011; Kinnischtzke et al., 2016). Sublaminar segregation in L6 also distinguishes different ET subtypes, but not IT from ET neu- rons. In the sensory cortex of multiple species, ET neurons located in more superficial (upper) L6 versus deeper (lower) L6 project to different subdivisions of thalamus (Bourassa and Deschênes, 1995; Usrey and Fitzpatrick, 1996; Zhang and Deschênes, 1997; Murphy et al., 2000). CT neurons in lower L6 of visual and somatosensory cortex project to both primary and secondary sensory thalamus, whereas CT neurons in upper L6 project to primary sensory thalamus only (Bourassa and Deschênes, 1995; Zhang and Deschênes, 1997; Killackey and Sherman, 2003; Chevée et al., 2018).

\section{Dendritic arbor}

Generally, the classification of "thick"- versus "thin"-tufted remains a useful segregator for ET and IT populations (Fig. 1) (Ramaswamy and Markram, 2015). On average, the width and/or total dendritic length of the apical tuft distinguishes L5 projection neuron types in all cortical regions studied (Gao and Zheng, 2004; Morishima and Kawaguchi, 2006; Brown and Hestrin, 2009a; Dembrow et al., 2010; Groh et al., 2010; Oswald et al., 2013; Ferreira et al., 2015; Joshi et al., 2015). For L6 neurons, the size of apical tuft also depends upon projection target. In rat, L6 ET neurons extend their apical dendrites vertically up to L4 or L5 and exhibit narrow tufts, whereas L6 IT neurons are tuftless with varying lengths of apical dendrites. L6 corticocortical neurons have apical dendrites projecting up to the borderline between L4 and L5 (Oberlaender et al., 2012; Vélez-Fort et al., 2014), whereas corticoclaustral neurons have dendrites extending to L1 (Katz, 1987; Thomson and Lamy, 2007; Cotel et al., 2017).

While, on average, ET and IT neurons exhibit distinct dendritic morphology, great variability in the apical dendritic arbor also exists within ET and IT subpopulations: some IT neurons have substantial apical tufts, whereas others lack a tuft altogether. Some of this variability correlates with cortical region and somatic depth (Ueta et al., 2014; Suter and Shepherd, 2015) and may be related to expression of specific genes (Tantirigama et al., 2014, 2016; Harb et al., 2016). In one L5 ET neuron subpopulation, the tuft size varies with the number of long-range projection locations (Guo et al., 2017a).

L5 and L6 neurons typically differ in their apical arbor morphology, although in some cases ET and IT subpopulations exhibit subtler differences in the basal dendrites (Katz, 1987; Zhang and Deschênes, 1997; Morishima and Kawaguchi, 2006; Kumar and Ohana, 2008; Hirai et al., 2012; Vélez-Fort et al., 2014). The enriched apical arbors of ET neurons relative to IT neurons suggest that ET neurons may integrate many more synaptic inputs arriving at the upper layers and thus may be integrating more inputs from "higher" cortical regions.

\section{Intrinsic electrophysiological properties}

Important differences in both the subthreshold and suprathreshold properties of DLPN populations have been identified from both in vivo and ex vivo recordings. These differences have implications for the ability of these neuron populations to integrate information across time. Across cortical areas, L5 ET neurons generally exhibit electrophysiological signatures that reflect the strong influence of hyperpolarization-activated nonselective cation (h)-currents. L5 PT neurons frequently have a more depolarized resting membrane potential, a lower input resistance, a faster effective membrane time constant, and often display a slow depolarization or "sag" potential in response to hyperpolarization relative to L5 IT neurons (Dembrow et al., 2010; Sheets and Shepherd, 2011; Avesar and Gulledge, 2012; Oswald et al., 2013; Kalmbach et al., 2015; Rock and Apicella, 2015; Anastasiades et 
al., 2018a; Baker et al., 2018), although some exceptions to this trend have been identified (Otsuka and Kawaguchi, 2008; Groh et al., 2010; Guan et al., 2015).

The time-dependent properties of h-channels impart distinct filtering properties in L5 PT neurons (Dembrow et al., 2010; Sheets and Shepherd, 2011; Ferreira et al., 2015; Kalmbach et al., 2015; Zurita et al., 2017; Anastasiades et al., 2018a). PT neurons are most responsive to sinusoidal current injections at the soma of $3-6 \mathrm{~Hz}$, whereas IT neurons optimally respond to slower $(<2.5$ $\mathrm{Hz}$ ) current oscillations. These h-current-related electrophysiological differences are accentuated in their apical dendrites (Kalmbach et al., 2013, 2015, 2017; Dembrow et al., 2015), where $\mathrm{h}$-channel expression in the apical arbor is particularly enriched in pyramidal neurons (Magee, 1998; Williams and Stuart, 2000; Berger et al., 2001; Lörincz et al., 2002; Berger and Lüscher, 2003; Kole et al., 2006; Harnett et al., 2015). The distinct filtering properties imparted by h-channels strongly shape how L5 PT neurons integrate incoming synaptic inputs (Lee et al., 2014; Dembrow et al., 2015; Anastasiades et al., 2018a). Most strikingly, h-channels make L5 PT neurons preferentially responsive to inputs along their apical dendrite that are clustered in time, making these neurons function more as coincidence detectors than temporal integrators (Dembrow et al., 2015; Kalmbach et al., 2017).

What causes the unique h-current-related properties in L5 PT neurons? Given the distinct molecular identity of these DLPN populations (see above), it is possible these channels are one central feature of this neuronal type. However, the presence of h-channels is not unique to L5 PT neurons: pharmacological blockade of h-current alters membrane properties of both PT and IT neurons (Dembrow et al., 2014; Ferreira et al., 2015; Kalmbach et al., 2015; Kinnischtzke et al., 2016). Furthermore, transcription levels of different h-channel subunits could account for these differences in motor cortex but not sensory cortices (Christophe et al., 2005), suggesting that these differences could also be due to post-translational effects, or differences in expression of the h-channel trafficking protein, Trip8b (Heuermann et al., 2016). Intriguingly, sensory deprivation can reduce h-current expression in the distal dendrites, suggesting that these channels are targets of experience-dependent plasticity (Breton and Stuart, 2009).

In contrast to neurons in L5, ET and IT populations in L6 do not consistently exhibit membrane properties in line with differences in h-currents (Kumar and Ohana, 2008; Vélez-Fort et al., 2014; Kinnischtzke et al., 2016; Cotel et al., 2017; Crandall et al., 2017; Zurita et al., 2017). L6 ET neurons do have a faster membrane time constant than L6 IT neurons. Unlike L5, CT and IT neurons in L6 do not have distinguishable dendritic physiology (Ledergerber and Larkum, 2010). Combined, these data indicate that, although both L5 and L6 ETs have narrower integration windows than IT neurons, only L5 PT neurons exhibit the bandpass properties that synchronize particular frequencies of synaptic inputs (Vaidya and Johnston, 2013; Dembrow et al., 2015).

Excitability of ET and IT neurons also differs between L5 and L6. In vivo recordings generally demonstrate that the "basal" firing rates of L5 PT neurons > IT neurons > L6 CT neurons (Swadlow, 1989; Sirota et al., 2005; Oberlaender et al., 2012; Vélez-Fort et al., 2014; Rojas-Piloni et al., 2017; Saiki et al., 2018). L5 PT neurons also often fire trains of 2-4 spikes at high frequencies (>100 Hz) (Mallet et al., 2006; de Kock and Sakmann, 2009; Pasquereau and Turner, 2011; Ushimaru and Kawaguchi, 2015; Rojas-Piloni et al., 2017), a property assumed to be a combination of intrinsic electrophysiological properties and patterns of synaptic input. While traditional descriptions of neurons being intrinsically bursting or regular spiking can be complicated by experimental conditions (Christophe et al., 2005; Bekkers and Häusser, 2007; Kole, 2011), differences in the firing properties of DLPN populations are nevertheless present in ex vivo slice recordings. When driven to fire an action potential (AP), L5 PT neurons consistently exhibit a lower AP voltage threshold than IT neurons across different cortices (Christophe et al., 2005; Hattox and Nelson, 2007; Dembrow et al., 2010; Kalmbach et al., 2015), whereas L6 ET neurons have a higher voltage threshold than L6 IT neurons (Kumar and Ohana, 2008; Kinnischtzke et al., 2016; Crandall et al., 2017; but see Cotel et al., 2017). The rheobase current, or minimal amount of steady-state current required to drive an AP, is dependent upon a combination of the resting membrane potential, input resistance, and the AP threshold. In some cases, rheobase measured in vitro corresponds with excitability observed in vivo (e.g., Crandall et al., 2017). However, the amount of steady-state current required to drive APs in L5 PT neurons is variable (Dembrow et al., 2010; Sheets et al., 2011; Oswald et al., 2013; Guan et al., 2015). Some of the variability in the excitability of PT neurons may be accounted for by distinct subpopulations of PT neurons (Hattox and Nelson, 2007; RojasPiloni et al., 2017), but differences in rheobase across PT, CT, and IT populations do not necessarily match their in vivo activity (Kumar and Ohana, 2008; Joshi et al., 2015; Kinnischtzke et al., 2016; Cotel et al., 2017; Crandall et al., 2017). One possible reason for this disparity is that static current injections at the soma may not accurately capture the input-output properties of these cells. Approaches taking into the spatiotemporal features of synaptic activity might more accurately reflect the excitability of these neurons in vivo.

When active, the firing profile of both L5 and L6 IT neurons exhibits spike frequency adaptation, with constant current injection the frequency of firing decreases with time, while many ET neurons display far less adaptation (Mercer et al., 2005; Morishima and Kawaguchi, 2006; Hattox and Nelson, 2007; Kumar and Ohana, 2008; Vélez-Fort et al., 2014; Crandall et al., 2017). In some cases, L5 PT neurons even exhibit spike frequency acceleration (Miller et al., 2008; Dembrow et al., 2010; Oswald et al., 2013). These differences are likely due to unique complements of voltage-gated potassium channels (Hattox and Nelson, 2007; Bishop et al., 2015; Guan et al., 2015; Kalmbach et al., 2015; Pathak et al., 2016).

Importantly, the intrinsic electrophysiological properties of ET and IT neurons are not fixed; they can be modified by neuromodulation and plasticity. Typically acting via G-protein-coupled receptors and second messenger cascades, neuromodulators can change the properties of individual or sets of ion channels and thereby alter the dynamic properties of a neuron. An emerging principle is that, depending upon the long-range target, DLPNs respond differently to the actions of the same neuromodulator (for review, see Shepherd, 2013; Dembrow and Johnston, 2014; Puig et al., 2015; Radnikow and Feldmeyer, 2018). The distinct actions of noradrenaline, acetylcholine, serotonin, and dopamine on PT versus IT neurons has been shown both with bath application of the neuromodulator, specific receptor agonists, or even when endogenously released from optogenetically activated neuromodulatory fibers (Joshi et al., 2015; Sparks et al., 2017; Baker et al., 2018). The actions of other neuromodulatory substances, such as adenosine, histamine, and neuropeptide transmitters, may also have disparate effects upon DLPN populations depending upon their long-range projection targets (McCormick et al., 1993; Li et al., 2010; van Aerde et al., 2015). The distinct responses of ET versus IT neurons to a particular neuromodulator may be the result of differing levels of subunit receptor 
expression, subcellular receptor localization, or intracellular signaling cascades and the ion channels that can be targeted by them. Understanding how these different DLPN subpopulations respond to multiple neuromodulatory substances and thus function in vivo during different behavioral states remains an exciting avenue for future study.

\section{Distinctive local and long-range synaptic connectivity of DLPNs}

Patterns of local excitatory synaptic connections vary across motor, sensory, and association cortices (Hooks et al., 2011; DeNardo et al., 2015). Nevertheless, organizing themes in how DLPNs are interconnected do emerge, suggesting that local connections may form functionally distinct subnetworks with different long-range projection targets.

\section{Local connectivity between DLPN populations}

For the purposes of this review, we focus on intralaminar connectivity between DLPN subpopulations (for interlaminar connectivity, see Thomson and Lamy, 2007; Shipp et al., 2013; Kawaguchi, 2017; Narayanan et al., 2017). Simultaneous recordings from the somata of multiple DLPNs have revealed general organizing principles of connectivity between DLPN types within a given cortical layer. Connectivity between IT and ET populations within a layer is directional; ET-to-IT connections are sparser and weaker than IT-to-ET-connections. (Mercer et al., 2005; Morishima and Kawaguchi, 2006; West et al., 2006; Brown and Hestrin, 2009b; Kiritani et al., 2012; Crandall et al., 2017). Additionally, within a layer, neurons of the same projection type connect with one another (with rates from 4\% to 18\%) (Morishima and Kawaguchi, 2006; Le Bé et al., 2007; Brown and Hestrin, 2009a; Morishima et al., 2011; Kiritani et al., 2012; Maruoka et al., 2017). In frontal cortex, there is higher reciprocity between individual PT neurons relative to that between IT neurons, and these connections have larger unitary currents (Morishima et al., 2011). Within L6, local excitatory connection rates are generally low $(\sim 3 \%)$, with preferential connections found within a given population subtype, although CT neurons make fewer local connections to excitatory neurons than IT neuron populations (Mercer et al., 2005; West et al., 2006; Lefort et al., 2009; Thomson, 2010). Finally, while short-term dynamics between DLPNs depends upon cortical region (Y. Wang et al., 2006; Berger et al., 2009), there is emerging evidence to suggest these dynamics may also be dependent on projection neuron. Several studies have reported that ET neurons' connections to other pyramidal neurons (particularly within the same population) tend to display more facilitation, whereas IT neurons' connections display more depression (Mercer et al., 2005; Le Bé et al., 2007; Morishima et al., 2011; Kiritani et al., 2012; Cotel et al., 2017; but see Kozloski et al., 2001).

\section{Interneuron connectivity with DLPN populations}

Cortical interneurons (INs) represent a powerful regulator of neighboring DLPNs; yet, many questions about the specificity of their connectivity within the excitatory network remain. GABAergic cells can be classified by molecular and developmental identities, firing patterns, and/or morphologies (Kawaguchi and Kubota, 1997; Markram et al., 2004; DeFelipe et al., 2013), from which many classifications arise (for more in-depth, see Ascoli, 2008; Rudy et al., 2011; Kepecs and Fishell, 2014; Taniguchi, 2014). We focus here on the connectivity of two major IN subtypes found in high densities in deep cortical layers with DLPNs: those expressing parvalbumin $\left(\mathrm{PV}^{+}\right)$and those expressing somatostatin $\left(\mathrm{SOM}^{+}\right)$(Butt et al., 2005; Cobos et al., 2006;
Fogarty et al., 2007; Butt et al., 2008; Naka and Adesnik, 2016; Tremblay et al., 2016).

GABAergic innervation occurs at distinct subcellular locations on DLPNs (Pouille et al., 2013). $\mathrm{PV}^{+}$INs, which exhibit fast spiking firing patterns, generally synapse perisomatically or onto the more proximal dendrites (Buhl et al., 1994; Kawaguchi and Kubota, 1997, 1998; Marlin and Carter, 2014; Kubota et al., 2015), whereas $\mathrm{SOM}^{+}$INs target distal dendritic domains of pyramidal neurons (Reyes et al., 1998; Di Cristo et al., 2004; Goldberg et al., 2004).

Several lines of evidence suggest that INs connect to DLPN populations with some specificity. Reprogramming supragranular neurons into L5 PT neurons by changing Fez2f expression (Fig. 1) alters the pattern of innervation they receive from $\mathrm{PV}^{+}$ INs (Ye et al., 2015). Upon activation of callosal afferents in mice, $\mathrm{PV}^{+}$cells preferentially innervate ET neurons (Lee et al., 2014; Ferreira et al., 2015; Anastasiades et al., 2018a), whereas callosal afferents can also preferentially drive excitation of IT neurons (Rock and Apicella, 2015). In contrast, within the L5 rat frontal cortex, $\mathrm{PV}^{+}$INs make nonselective connections of equal magnitude with both IT and ET neurons (Morishima et al., 2017). Although these differences may be attributable to cross-species and cross-cortical connectivity, it is also possible that particular afferent fibers may recruit distinct sets of INs, and thus distinct feedforward inhibition. It should also be emphasized that subclassifications within ET and IT neurons, and within $\mathrm{PV}^{+}$and $\mathrm{SOM}^{+}$INs, exist, and that an additional level of specificity may play a role the diversity of findings (Reiner et al., 2003; Molnár and Cheung, 2006; Ascoli, 2008; Shepherd, 2013; Taniguchi, 2014). SOM ${ }^{+}$INs exhibit heterogeneous firing patterns, such as low threshold spike, and have diversity in input resistance (Ri) correlated to their dendritic morphologies. $\mathrm{SOM}^{+}$cells with high Ri preferentially innervate PT neurons, whereas low threshold spike cells with low Ri innervate IT neurons (Morishima et al., 2017). Further, a subset of $\mathrm{SOM}^{+}$INS, which forms synapses onto the distal dendrites of DLPNs, coordinates the firing of thick-tufted L5 neurons through preferential and reciprocal connectivity (Hilscher et al., 2017).

In both L5 and L6, ET neurons innervate IN subtypes differently, either more robustly than IT neurons (L5: Morishima et al., 2017; L6: Mercer et al., 2005; West et al., 2006) or with different synaptic properties (L5: Fariñas and DeFelipe, 1991; Angulo et al., 2003). In L6, neurons capitalize on synaptic connectivity with INs somatically positioned in deep layers to exert gain control in superficial layers. For example, L6 CT, but not IT, neurons have been shown to drive $\mathrm{PV}^{+}$and $\mathrm{SOM}^{+}$INs within $\mathrm{L} 6$ and in upper layers (Bortone et al., 2014; J. Kim et al., 2014), in turn exerting widespread inhibition across all cortical layers (Bortone et al., 2014). In visual cortex, L6 IT and CT neurons work in conjunction to control gain in neurons of superficial layers without changing their tuning to orientation (Olsen et al., 2012). Finally, in the auditory forebrain, optogenetic activation of L6 CT neurons during sensory stimulation yielded a switch in sound processing, between hypersensitive sound detection or dampened excitability and enhanced sound discrimination (Guo et al., 2017b).

\section{Long-range afferent and efferent connectivity}

Afferent input to infragranular layers has been extensively reviewed (Petreanu et al., 2009; Briggs, 2010; Feldmeyer, 2012; Hooks et al., 2013; Anastasiades et al., 2018b) and represents a significant area of research outside the scope of this review; however, we would like to highlight a few recent discoveries. First, 
afferent input preferentially innervates specific DLPN populations (Anderson et al., 2010; Mao et al., 2011). In the somatosensory cortex, Ntsr-1 ${ }^{+}$L6 CT neurons only weakly respond to input from the ventral posterior medial nucleus and are largely nonresponsive to input from the posterior medial nucleus; in contrast, Ntsr1 ${ }^{-}$L6 neurons receive strong thalamocortical input from the ventral posterior medial nucleus (Crandall et al., 2017). Anatomical studies using retrograde tracing methods show differences in local and long-range connectivity between different types of L6 projection neurons. For example, in primary visual cortex, the majority of input to L6 IT neurons originates from intra-areal local projection neurons residing in L2-L6 (Vélez-Fort et al., 2014). In contrast, L6 ET neurons received relatively few intra-areal, but significantly more inputs from secondary visual and retrosplenial cortices (Vélez-Fort et al., 2014). Finally, emerging evidence suggests that afferent input from a given brain region can target specific dendritic compartments of a particular DLPN type: in L5 of mPFC, the apical dendrite of IT, but not ET, neurons receives monosynaptic hippocampal input. However, both L5 DLPN types receive perisomatic hippocampal input (Dembrow et al., 2015).

\section{Functional implications of DLPN populations in vivo}

Evolving techniques for targeting specific cell types are enabling the study and manipulation of DLPN subpopulations during behavior at an unprecedented scale. Keeping in mind the caveats raised when using genetic and viral approaches to target different DLPN subpopulations (see above), selectively manipulating subpopulations of DLPNs can alter behavioral performance in robust and specific ways. Selectively stimulating subpopulations of DLPNs in the PFC biases rodents' behavioral state within aversive and/or reward-seeking contexts (Warden et al., 2012; C. K. Kim et al., 2017). Stimulating or impairing specific DLPNs in auditory and secondary motor cortices alters per-

formance in auditory discrimination (Bajo et al., 2010; Bajo and King, 2012; Znamenskiy and Zador, 2013; Schneider et al., 2014; Xiong et al., 2015). In addition, laminar electrode array recordings coupled with optogenetics and advances in imaging techniques and calcium indicators now allow cell specific monitoring of in vivo activity in DLPN subpopulations.

DLPN populations' role in sensory processing and behavior ET and IT populations exhibit distinct response properties to passive sensation (Fig. 2). In L5 visual cortex, ET neurons have broader orientation selectivity and higher temporal sensitivity than IT neu-

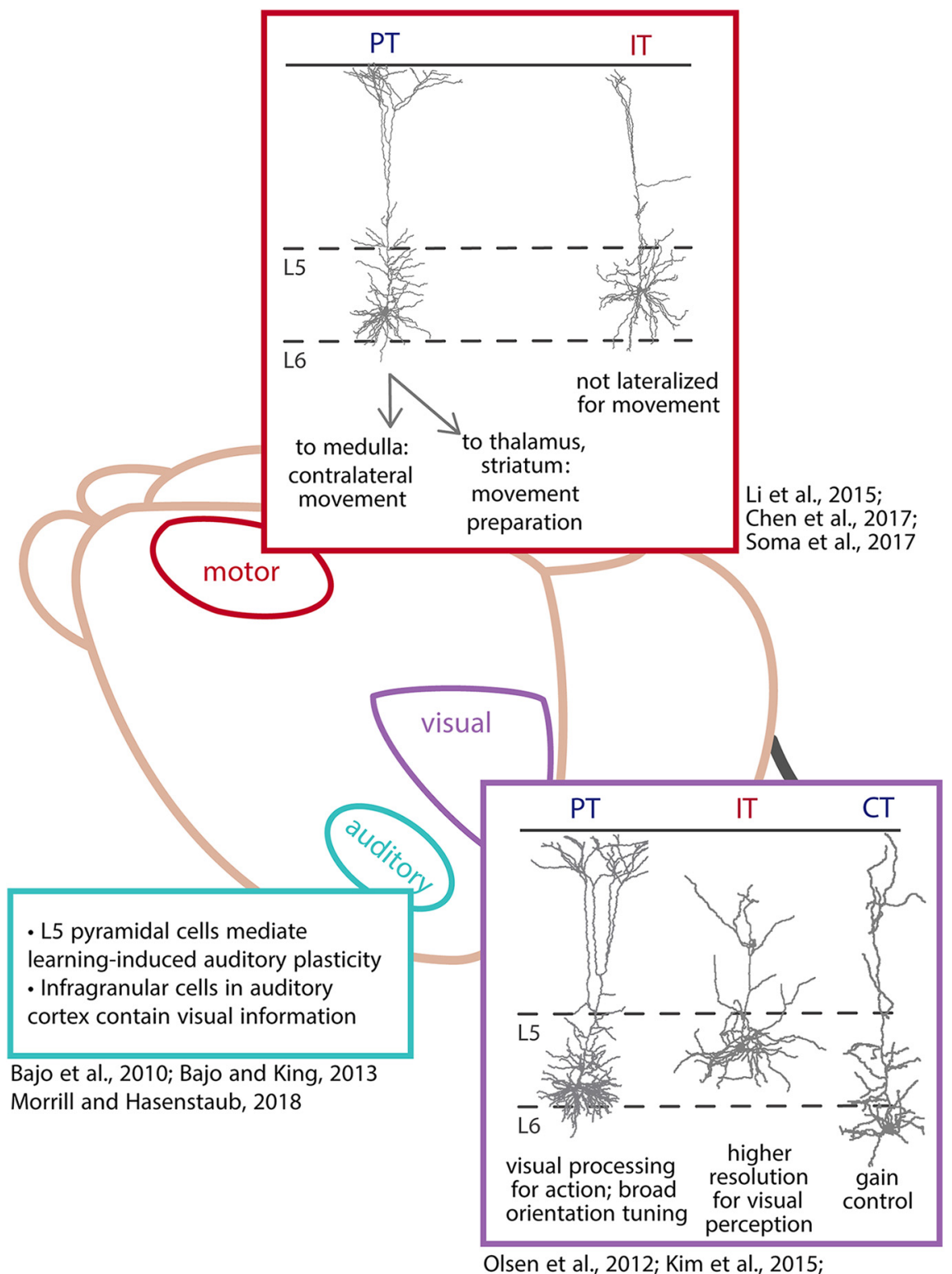

Olsen et al., 2012; Kim et al., 2015;

Lur et al., 2016

Figure 2. Functional implications of DLPNs. In vivo interrogations of DLPN in various cortical regions have begun to link different DLPNs to distinct function. For example, in visual cortex, L5 PT neurons participate in visual processing of movement and display broad orientation tuning, whereas L5 IT neurons are involved in high-resolution visual acuity. L6 CT neurons control the gain of the output of the cortical circuit. In motor cortex, L5 IT and PT neurons play distinct roles in guiding movement. IT neurons distribute information related to movement planning to other cortical regions and basal ganglia. IT neurons linking cortical hemispheres through the corpus callosum maintain robustness through redundancy. Thalamus-projecting PT neurons are involved in motor planning via the thalamo-cortical loop. Brainstem-projecting PT neurons send command signals to initiate contralateral movements. Additionally, in auditory cortex, L6 IT neurons participate in multimodal integration and L5ET neurons in learning-induced plasticity of sound localization. Reconstructed pyramidal neurons from Mieko Morishima, or from www. NeuroMorpho.0rg. IDs: 12606-MV-2p (CT), 126012-MV-2f (corticocortical).

rons. The response properties of IT neurons can be further divided into subpopulations depending upon their projection target. Corticostriatal IT neurons exhibit lower spatial frequency sensitivity compared with IT neurons whose projections are restricted to cortex (E. J. Kim et al., 2015; Lur et al., 2016). Similarly, distinct response properties of subpopulations of L5 PT neurons that project to the thalamus versus the brainstem are observed in rat barrel cortex following a gentle whisker deflection (Rojas-Piloni et al., 2017).

In L6, the selectivity patterns of ET versus IT are inverted: IT cells are more broadly tuned, whereas L6 CT cells have tighter 
orientation selectivity and fire sparsely (Oberlaender et al., 2012; Vélez-Fort et al., 2014). Emerging evidence across species demonstrates that L6 CT neurons play a central role in modulating thalamic and cortical neurons during sensory processing. Optogenetic and pharmacologic modulation of L6 CT neurons facilitates or depresses sensory thalamic responses, and changes the size or shifts the location of the center of the receptive field (W. Wang et al., 2006, 2018; Olsen et al., 2012; Denman and Contreras, 2015). In vivo experiments in the mouse visual cortex demonstrate that excitation of L6 CT neurons decreases the activity of cortical neurons by disynaptic inhibition of excitatory neurons through local and translaminar inhibitory neurons (Olsen et al., 2012; Bortone et al., 2014). The function of L6 IT neurons, which are in a unique position to integrate local streams of activity with incoming thalamic input (Crandall et al., 2017), remains elusive. These neurons may participate in shaping movement-related changes to sensory processing (Dadarlat and Stryker, 2017) and possibly even multimodal integration (Morrill and Hasenstaub, 2018).

\section{L5 PT and IT neurons in movement guidance}

Motor cortex, which plays an important role in the preparation and execution of voluntary movements (Shenoy et al., 2013; Svoboda and Li, 2018), exhibits movement-related activity, which is most prominent in L5 (Chandrasekaran et al., 2017). Recordings in primates during instructed movements that temporally separate movement preparation and execution demonstrate that PT activity is more correlated with parameters of movement execution (e.g., reaction time, muscle activation patterns), and activity in IT neurons is more correlated with movement preparation (Tanji and Evarts, 1976; Kubota and Hamada, 1979; Turner and DeLong, 2000). However, considerable overlap exists between the two populations, and prominent preparatory activity occurs in PT neurons (Tanji and Evarts, 1976; Turner and DeLong, 2000).

Recent studies have allowed further in-depth characterization of the roles of L5 IT and PT activity in rodents during movement preparation and execution (Fig. 2) (Li et al., 2015; Chen et al., 2017; Peters et al., 2017; Soma et al., 2017). In both primary and secondary motor cortices, PT neurons preferentially code for contralateral limb movement, whereas IT neurons code for both arms (Soma et al., 2017). The contra-preference in PT neurons mirrors another finding in mice examining direction selectivity of IT and PT neurons during instructed tongue movements, where selectivity for tongue movements to the contralateral direction emerges in and can be driven by PT neurons ( $\mathrm{Li}$ et al., 2015). This is consistent with PT neurons' contra-biased projection patterns in the brainstem (Zhang and Sasamoto, 1990; Li et al., 2015) and spinal cord (Rouiller et al., 1993). Importantly, in both studies, the contra-preference only emerged in PT neurons right before movement onset, consistent with a motor command signal that triggers the movement. In parallel, IT neurons may help maintain the robustness of preparatory activity via projections across the corpus callosum (Li et al., 2016). Together, these studies demonstrate that information from motor cortex is not distributed evenly to all downstream areas. Rather, distinct projection neurons send different types of information related to movement preparation and motor command to different downstream regions, with IT neurons sending task-related information related to movement preparation to the basal ganglia and cortex whereas brainstem-projecting PT neurons may be involved in initiating and executing well-timed movements ( $\mathrm{Li}$ et al., 2015; Chen et al., 2017).
Notably, there is considerable diversity in the response profiles of PT neurons associated with movement (Tanji and Evarts, 1976; Turner and DeLong, 2000; Li et al., 2015; Chen et al., 2017; Peters et al., 2017; Soma et al., 2017; Saiki et al., 2018). For example, many PT neurons respond well before movement onset, whereas others respond only around the time of movement. This diversity is partly reflective of the fact that PT neurons are comprised of several subpopulations (Hattox and Nelson, 2007; Hirai et al., 2012; Kita and Kita, 2012; Ueta et al., 2014; Rojas-Piloni et al., 2017). One particularly important output for L5 PT neurons is to the thalamus, which maintains preparatory activity through a recurrent thalamocortical loop (Guo et al., 2017b). Combining brainwide single-neuron reconstructions (Economo et al., 2016) and transcriptional profiling to reconcile diverse motor cortex responses will provide a particularly powerful approach to dissecting motor cortex functions.

\section{Role of DLPNs in pathophysiological states}

The massive diversity in genetic, cellular, and functional properties of DLPNs sets an organized framework for subtype-specific contributions to nervous system disorder. Several subtypes of DLPNs have been implicated in disorders, such as schizophrenia, epilepsy, amyotrophic lateral sclerosis (ALS), and autism spectrum disorders. Ultimately, understanding the roles of these cell types across multiple cortices and experimental preparations will deepen our understanding of what happens when the function of these cell types goes awry.

Indeed, several lines of evidence from mouse and primate models implicate specific DLPN subtypes in dysfunction. A lossof-function mutation in $\mathrm{P} / \mathrm{Q} \mathrm{Ca}^{2+}$ channel pore complexes specifically in L6 CT neurons recapitulates many of the phenotypes observed in absence epilepsy (Maheshwari and Noebels, 2014; Bomben et al., 2016). In a mouse model of SOD1-ALS, corticospinal motor neurons, a subtype of L5B PT neuron of the motor cortex, selectively degenerates (Rosen et al., 1993; Gurney et al., 1994; Özdinler et al., 2011; Jara et al., 2012; Fogarty et al., 2016a, b, 2017; Saba et al., 2016). While multiple neuron subtypes exhibit increased intrinsic excitability and altered transcriptional profiles in this mouse model of ALS, the complement of mRNA transcripts that were affected were cell type-specific (J. Kim et al., 2017). These results suggest that unique molecular responses of PT and IT cell types may contribute to their differing vulnerabilities. In the same vein, in mouse models of Fragile X syndrome, the leading identified genetic cause of autism, the functional expression of several ion channels is altered in L5 ET, but not IT, neurons (Zhang et al., 2014; Kalmbach et al., 2015). Consequently, L5 ET neurons in Fragile X syndrome mice are more excitable than in their wild-type counterparts. Finally, there is evidence in nonrodent species for cell type-specific contributions to nervous system disorders. For example, in a monkey model of Parkinson's disease, the in vivo activity of PT neurons is altered, whereas IT neural activity is relatively unaffected (Pasquereau and Turner, 2011, 2013; Pasquereau et al., 2016). These are just a few of many examples of cell type-specific alterations to neuron function associated with nervous system disorders and underscore the crucial need to develop therapies that target specific populations of cells toward the treatment of nervous system disorders.

In conclusion, we have highlighted here the genetic, physiological, morphological, synaptic, and functional features that define broad classes of DLPN. The striking variability of these features is obvious, even within a given class of DLPN. It is increasingly apparent that multiple subtypes of neurons exist 
within each broad class of DLPN. Outstanding questions to be addressed by future research include: How many types of DLPNs exist? Are the same DLPN subpopulations found ubiquitously throughout neocortex? Are there cross-species differences in DLPN features and functions? How does variability in morphology, axonal targeting, and gene expression correspond to differences in physiology and function? Ultimately, tackling these questions will unravel the mysteries underlying cortical function and lead to new therapies for nervous system disorders.

\section{References}

Adesnik H, Scanziani M (2010) Lateral competition for cortical space by layer-specific horizontal circuits. Nature 464:1155-1160. CrossRef Medline

Alcamo EA, Chirivella L, Dautzenberg M, Dobreva G, Fariñas I, Grosschedl R, McConnell SK (2008) Satb2 regulates callosal projection neuron identity in the developing cereb cortex. Neuron 57:364-377. CrossRef Medline

Anastasiades PG, Marlin JJ, Carter AG (2018a) Cell type-specificity of callosally evoked excitation and feedforward inhibition in the prefrontal cortex. Cell Rep 22:679-692. CrossRef Medline

Anastasiades PG, Marques-Smith A, Butt SJ (2018b) Studies of cortical connectivity using optical circuit mapping methods. J Physiol 596:145-162. CrossRef Medline

Anderson CT, Sheets PL, Kiritani T, Shepherd GM (2010) Sublayer-specific microcircuits of corticospinal and corticostriatal neurons in motor cortex. Nat Neurosci 13:739-744. CrossRef Medline

Angevine JB Jr, Sidman RL (1961) Autoradiographic study of cell migration during histogenesis of cerebral cortex in the mouse. Nature 192:766-768. CrossRef Medline

Angulo MC, Staiger JF, Rossier J, Audinat E (2003) Distinct local circuits between neocortical pyramidal cells and fast-spiking interneurons in young adult rats. J Neurophysiol 89:943-953. CrossRef Medline

Arlotta P, Molyneaux BJ, Chen J, Inoue J, Kominami R, Macklis JD (2005) Neuronal subtype-specific genes that control corticospinal motor neuron development in vivo. Neuron 45:207-221. CrossRef Medline

Ascoli GA (2008) Neuroinformatics grand challenges. Neuroinformatics 6:1-3. CrossRef Medline

Avesar D, Gulledge AT (2012) Selective serotonergic excitation of callosal projection neurons. Front Neural Circuits 6:12. CrossRef Medline

Bajo VM, King AJ (2012) Cortical modulation of auditory processing in the midbrain. Front Neural Circuits 6:114. CrossRef Medline

Bajo VM, Nodal FR, Moore DR, King AJ (2010) The descending corticocollicular pathway mediates learning-induced auditory plasticity. Nat Neurosci 13:253-260. CrossRef Medline

Baker AL, O’Toole RJ, Gulledge AT (2018) Preferential cholinergic excitation of corticopontine neurons. J Physiol 569 9:1659-1679. CrossRef Medline

Bakken T, Cowell L, Aevermann BD, Novotny M, Hodge R, Miller JA, Lee A, Chang I, McCorrison J, Pulendran B, Qian Y, Schork NJ, Lasken RS, Lein ES, Scheuermann RH (2017) Cell type discovery and representation in the era of high-content single cell phenotyping. BMC Bioinformatics 18: 559. CrossRef Medline

Bedogni F, Hodge RD, Elsen GE, Nelson BR, Daza RA, Beyer RP, Bammler TK, Rubenstein JL, Hevner RF (2010) Tbr1 regulates regional and laminar identity of postmitotic neurons in developing neocortex. Proc Natl Acad Sci U S A 107:13129-13134. CrossRef Medline

Bekkers JM, Häusser M (2007) Targeted dendrotomy reveals active and passive contributions of the dendritic tree to synaptic integration and neuronal output. Proc Natl Acad Sci U S A 104:11447-11452. CrossRef Medline

Berger T, Lüscher HR (2003) Timing and precision of spike initiation in layer V pyramidal cells of the rat somatosensory cortex. Cereb Cortex 13:274-281. CrossRef Medline

Berger TK, Perin R, Silberberg G, Markram H (2009) Frequency-dependent disynaptic inhibition in the pyramidal network: a ubiquitous pathway in the developing rat neocortex. J Physiol 587:5411-5425. CrossRef Medline

Berger T, Larkum ME, Lüscher HR (2001) High I(h) channel density in the distal apical dendrite of layer $\mathrm{V}$ pyramidal cells increases bidirectional attenuation of EPSPs. J Neurophysiol 85:855-868. CrossRef Medline

Bishop HI, Guan D, Bocksteins E, Parajuli LK, Murray KD, Cobb MM, Mis- onou H, Zito K, Foehring RC, Trimmer JS (2015) Distinct cell- and layer-specific expression patterns and independent regulation of Kv2 channel subtypes in cortical pyramidal neurons. J Neurosci 35:1492214942. CrossRef Medline

Bitzenhofer SH, Ahlbeck J, Wolff A, Wiegert JS, Gee CE, Oertner TG, Hanganu-Opatz IL (2017) Layer-specific optogenetic activation of pyramidal neurons causes beta-gamma entrainment of neonatal networks. Nat Commun 8:14563. CrossRef Medline

Bomben VC, Aiba I, Qian J, Mark MD, Herlitze S, Noebels JL (2016) Isolated P/Q calcium channel deletion in layer VI corticothalamic neurons generates absence epilepsy. J Neurosci 36:405-418. CrossRef Medline

Bortone DS, Olsen SR, Scanziani M (2014) Translaminar inhibitory cells recruited by layer 6 corticothalamic neurons suppress visual cortex. Neuron 82:474-485. CrossRef Medline

Bourassa J, Deschênes M (1995) Corticothalamic projections from the primary visual cortex in rats: a single fiber study using biocytin as an anterograde tracer. Neuroscience 66:253-263. CrossRef Medline

Breton JD, Stuart GJ (2009) Loss of sensory input increases the intrinsic excitability of layer 5 pyramidal neurons in rat barrel cortex. J Physiol 587:5107-5119. CrossRef Medline

Briggs F (2010) Organizing principles of cortical layer 6. Front Neural Circuits 4:3. CrossRef Medline

Briggs F, Usrey WM (2008) Emerging views of corticothalamic function. Curr Opin Neurobiol 18:403-407. CrossRef Medline

Britanova O, de Juan Romero C, Cheung A, Kwan KY, Schwark M, Gyorgy A, Vogel T, Akopov S, Mitkovski M, Agoston D, Sestan N, Molnár Z, Tarabykin V (2008) Satb2 is a postmitotic determinant for upper-layer neuron specification in the neocortex. Neuron 57:378-392. CrossRef Medline

Brown SP, Hestrin S (2009a) Intracortical circuits of pyramidal neurons reflect their long-range axonal targets. Nature 457:1133-1136. CrossRef Medline

Brown SP, Hestrin S (2009b) Cell-type identity: a key to unlocking the function of neocortical circuits. Curr Opin Neurobiol 19:415-421. CrossRef Medline

Buhl EH, Halasy K, Somogyi P (1994) Diverse sources of hippocampal unitary inhibitory postsynaptic potentials and the number of synaptic release sites. Nature 368:823-828. CrossRef Medline

Butt SJ, Fuccillo M, Nery S, Noctor S, Kriegstein A, Corbin JG, Fishell G (2005) The temporal and spatial origins of cortical interneurons predict their physiological subtype. Neuron 48:591-604. CrossRef Medline

Butt SJ, Sousa VH, Fuccillo MV, Hjerling-Leffler J, Miyoshi G, Kimura S, Fishell G (2008) The requirement of Nkx2-1 in the temporal specification of cortical interneuron subtypes. Neuron 59:722-732. CrossRef Medline

Cánovas J, Berndt FA, Sepúlveda H, Aguilar R, Veloso FA, Montecino M, Oliva C, Maass JC, Sierralta J, Kukuljan M (2015) The specification of cortical subcerebral projection neurons depends on the direct repression of TBR1 by CTIP1/BCL11a. J Neurosci 35:7552-7564. CrossRef Medline

Chandrasekaran C, Peixoto D, Newsome WT, Shenoy KV (2017) Laminar differences in decision-related neural activity in dorsal premotor cortex. Nat Commun 8:614. CrossRef Medline

Chen B, Schaevitz LR, McConnell SK (2005) Fezl regulates the differentiation and axon targeting of layer 5 subcortical projection neurons in cerebral cortex. Proc Natl Acad Sci U S A 102:17184-17189. CrossRef Medline

Chen TW, Li N, Daie K, Svoboda K (2017) A map of anticipatory activity in mouse motor cortex. Neuron 94:866-879.e4. CrossRef Medline

Chevée M, Robertson JJ, Cannon GH, Brown SP, Goff LA (2018) Variation in activity state, axonal projection, and position define the transcriptional identity of individual neocortical projection neurons. Cell Rep 22:441455. CrossRef Medline

Christophe E, Doerflinger N, Lavery DJ, Molnár Z, Charpak S, Audinat E (2005) Two populations of layer $V$ pyramidal cells of the mouse neocortex: development and sensitivity to anesthetics. J Neurophysiol 94:33573367. CrossRef Medline

Cobos I, Seeley WW (2015) Human von Economo neurons express transcription factors associated with layer $\mathrm{V}$ subcerebral projection neurons. Cereb Cortex 25:213-220. CrossRef Medline

Cobos I, Long JE, Thwin MT, Rubenstein JL (2006) Cellular patterns of transcription factor expression in developing cortical interneurons. Cereb Cortex 16 [Suppl 1]:i82-i88.

Connors BW, Gutnick MJ, Prince DA (1982) Electrophysiological proper- 
ties of neocortical neurons in vitro. J Neurophysiol 48:1302-1320. CrossRef Medline

Costa MR, Müller U (2014) Specification of excitatory neurons in the developing cerebral cortex: progenitor diversity and environmental influences. Front Cell Neurosci 8:449. CrossRef Medline

Cotel F, Fletcher LN, Kalita-de Croft S, Apergis-Schoute J, Williams SR (2017) Cell class-dependent intracortical connectivity and output dynamics of layer 6 projection neurons of the rat primary visual cortex. Cereb Cortex 27:1-11. CrossRef Medline

Crandall SR, Patrick SL, Cruikshank SJ, Connors BW (2017) Infrabarrels are layer 6 circuit modules in the barrel cortex that link long-range inputs and outputs. Cell Rep 21:3065-3078. CrossRef Medline

Dadarlat MC, Stryker MP (2017) Locomotion enhances neural encoding of visual stimuli in mouse V1. J Neurosci 37:3764-3775. CrossRef Medline

DeFelipe J, López-Cruz PL, Benavides-Piccione R, Bielza C, Larrañaga P, Anderson S, Burkhalter A, Cauli B, Fairén A, Feldmeyer D, Fishell G, Fitzpatrick D, Freund TF, González-Burgos G, Hestrin S, Hill S, Hof PR, Huang J, Jones EG, Kawaguchi Y, et al. (2013) New insights into the classification and nomenclature of cortical GABAergic interneurons. Nat Rev Neurosci 14:202-216. CrossRef Medline

DeFelipe J, Alonso-Nanclares L, Arellano JI (2002) Microstructure of the neocortex: comparative aspects. J Neurocytol 31:299-316. CrossRef Medline

de Kock CP, Sakmann B (2009) Spiking in primary somatosensory cortex during natural whisking in awake head-restrained rats is cell type-specific. Proc Natl Acad Sci U S A 106:16446-16450. CrossRef Medline

De la Rossa A, Bellone C, Golding B, Vitali I, Moss J, Toni N, Lüscher C, Jabaudon D (2013) In vivo reprogramming of circuit connectivity in postmitotic neocortical neurons. Nat Neurosci 16:193-200. CrossRef Medline

Dembrow N, Johnston D (2014) Subcircuit-specific neuromodulation in the prefrontal cortex. Front Neural Circuits 8:54. CrossRef Medline

Dembrow NC, Chitwood RA, Johnston D (2010) Projection-specific neuromodulation of medial prefrontal cortex neurons. J Neurosci 30:1692216937. CrossRef Medline

Dembrow NC, Zemelman BV, Johnston D (2015) Temporal dynamics of L5 dendrites in medial prefrontal cortex regulate integration versus coincidence detection of afferent inputs. J Neurosci 35:4501-4514. CrossRef Medline

DeNardo LA, Berns DS, DeLoach K, Luo L (2015) Connectivity of mouse somatosensory and prefrontal cortex examined with trans-synaptic tracing. Nat Neurosci 18:1687-1697. CrossRef Medline

Denman DJ, Contreras D (2015) Complex effects on in vivo visual responses by specific projections from mouse cortical layer 6 to dorsal lateral geniculate nucleus. J Neurosci 35:9265-9280. CrossRef Medline

Di Cristo G, Wu C, Chattopadhyaya B, Ango F, Knott G, Welker E, Svoboda K, Huang ZJ (2004) Subcellular domain-restricted GABAergic innervation in primary visual cortex in the absence of sensory and thalamic inputs. Nat Neurosci 7:1184-1186. CrossRef Medline

Doyle JP, Dougherty JD, Heiman M, Schmidt EF, Stevens TR, Ma G, Bupp S, Shrestha P, Shah RD, Doughty ML, Gong S, Greengard P, Heintz N (2008) Application of a translational profiling approach for the comparative analysis of CNS cell types. Cell 135:749-762. CrossRef Medline

Economo MN, Clack NG, Lavis LD, Gerfen CR, Svoboda K, Myers EW, Chandrashekar J (2016) A platform for brain-wide imaging and reconstruction of individual neurons. Elife 5:e10566. CrossRef Medline

Fame RM, MacDonald JL, Macklis JD (2011) Development, specification, and diversity of callosal projection neurons. Trends Neurosci 34:41-50. CrossRef Medline

Fame RM, Dehay C, Kennedy H, Macklis JD (2017) Subtype-specific genes that characterize subpopulations of callosal projection neurons in mouse identify molecularly homologous populations in macaque cortex. Cereb Cortex 27:1817-1830. CrossRef Medline

Fariñas I, DeFelipe J (1991) Patterns of synaptic input on corticocortical and corticothalamic cells in the cat visual cortex: II. The axon initial segment. J Comp Neurol 304:70-77. CrossRef Medline

Feldmeyer D (2012) Excitatory neuronal connectivity in the barrel cortex. Front Neuroanat 6:24. CrossRef Medline

Feng G, Mellor RH, Bernstein M, Keller-Peck C, Nguyen QT, Wallace M, Nerbonne JM, Lichtman JW, Sanes JR (2000) Imaging neuronal subsets in transgenic mice expressing multiple spectral variants of GFP. Neuron 28:41-51. CrossRef Medline
Ferreira AN, Yousuf H, Dalton S, Sheets PL (2015) Highly differentiated cellular and circuit properties of infralimbic pyramidal neurons projecting to the periaqueductal gray and amygdala. Front Cell Neurosci 9:161. CrossRef Medline

Fogarty MJ, Klenowski PM, Lee JD, Drieberg-Thompson JR, Bartlett SE, Ngo ST, Hilliard MA, Bellingham MC, Noakes PG (2016a) Cortical synaptic and dendritic spine abnormalities in a presymptomatic TDP-43 model of amyotrophic lateral sclerosis. Sci Rep 6:37968. CrossRef Medline

Fogarty MJ, Mu EW, Noakes PG, Lavidis NA, Bellingham MC (2016b) Marked changes in dendritic structure and spine density precede significant neuronal death in vulnerable cortical pyramidal neuron populations in the SOD1(G93A) mouse model of amyotrophic lateral sclerosis. Acta Neuropathol Commun 4:77. CrossRef Medline

Fogarty MJ, Mu EW, Lavidis NA, Noakes PG, Bellingham MC (2017) Motor areas show altered dendritic structure in an amyotrophic lateral sclerosis mouse model. Front Neurosci 11:609. CrossRef Medline

Fogarty M, Grist M, Gelman D, Marín O, Pachnis V, Kessaris N (2007) Spatial genetic patterning of the embryonic neuroepithelium generates GABAergic interneuron diversity in the adult cortex. J Neurosci 27: 10935-10946. CrossRef Medline

Gal JS, Morozov YM, Ayoub AE, Chatterjee M, Rakic P, Haydar TF (2006) Molecular and morphological heterogeneity of neural precursors in the mouse neocortical proliferative zones. J Neurosci 26:1045-1056. CrossRef Medline

Galazo MJ, Emsley JG, Macklis JD (2016) Corticothalamic projection neuron development beyond subtype specification: Fog2 and intersectional controls regulate intraclass neuronal diversity. Neuron 91:90-106. CrossRef Medline

Gao WJ, Zheng ZH (2004) Target-specific differences in somatodendritic morphology of layer V pyramidal neurons in rat motor cortex. J Comp Neurol 476:174-185. CrossRef Medline

Gerfen CR, Paletzki R, Heintz N (2013) GENSAT BAC cre-recombinase driver lines to study the functional organization of cerebral cortical and basal ganglia circuits. Neuron 80:1368-1383. CrossRef Medline

Goldberg JH, Lacefield CO, Yuste R (2004) Global dendritic calcium spikes in mouse layer 5 low threshold spiking interneurones: implications for control of pyramidal cell bursting. J Physiol 558:465-478. CrossRef Medline

Gong S, Doughty M, Harbaugh CR, Cummins A, Hatten ME, Heintz N, Gerfen CR (2007) Targeting Cre recombinase to specific neuron populations with bacterial artificial chromosome constructs. J Neurosci 27: 9817-9823. CrossRef Medline

Gray LT, Yao Z, Nguyen TN, Kim TK, Zeng H, Tasic B (2017) Layer-specific chromatin accessibility landscapes reveal regulatory networks in adult mouse visual cortex. Elife 6:e21883. CrossRef Medline

Groh A, Meyer HS, Schmidt EF, Heintz N, Sakmann B, Krieger P (2010) Cell type-specific properties of pyramidal neurons in neocortex underlying a layout that is modifiable depending on the cortical area. Cereb Cortex 20:826-836. CrossRef Medline

Guan D, Armstrong WE, Foehring RC (2015) Electrophysiological properties of genetically identified subtypes of layer 5 neocortical pyramidal neurons: $\mathrm{Ca}^{2+}$ dependence and differential modulation by norepinephrine. J Neurophysiol 113:2014-2032. CrossRef Medline

Guo C, Peng J, Zhang Y, Li A, Li Y, Yuan J, Xu X, Ren M, Gong H, Chen S (2017a) Single-axon level morphological analysis of corticofugal projection neurons in mouse barrel field. Sci Rep 7:2846. CrossRef Medline

Guo ZV, Inagaki HK, Daie K, Druckmann S, Gerfen CR, Svoboda K (2017b) Maintenance of persistent activity in a frontal thalamocortical loop. Nature 545:181-186. CrossRef Medline

Gurney ME, Pu H, Chiu AY, Dal Canto MC, Polchow CY, Alexander DD, Caliendo J, Hentati A, Kwon YW, Deng HX (1994) Motor neuron degeneration in mice that express a human $\mathrm{Cu}, \mathrm{Zn}$ superoxide dismutase mutation. Science 264:1772-1775. CrossRef Medline

Han Y, Kebschull JM, Campbell RAA, Cowan D, Imhof F, Zador AM, MrsicFlogel TD (2018) The logic of single-cell projections from visual cortex. Nature 556:51-56. CrossRef

Harb K, Magrinelli E, Nicolas CS, Lukianets N, Frangeul L, Pietri M, Sun T, Sandoz G, Grammont F, Jabaudon D, Studer M, Alfano C (2016) Areaspecific development of distinct projection neuron subclasses is regulated by postnatal epigenetic modifications. Elife 5:e09531. CrossRef Medline Harnett MT, Magee JC, Williams SR (2015) Distribution and function of 
HCN channels in the apical dendritic tuft of neocortical pyramidal neurons. J Neurosci 35:1024-1037. CrossRef Medline

Harris JA, Hirokawa KE, Sorensen SA, Gu H, Mills M, Ng LL, Bohn P, Mortrud M, Ouellette B, Kidney J, Smith KA, Dang C, Sunkin S, Bernard A, Oh SW, Madisen L, Zeng H (2014) Anatomical characterization of Cre driver mice for neural circuit mapping and manipulation. Front Neural Circuits 8:76. CrossRef Medline

Hasse JM, Bragg EM, Murphy AJ, Briggs F (2018) Morphological heterogeneity among corticogeniculate neurons in ferrets: quantification and comparison with a previous report in macaque monkeys. J Comp Neurol. Advance online publication. Retrieved Apr. 17, 2018. doi: 10.1002/ cne.24451. CrossRef Medline

Hattox AM, Nelson SB (2007) Layer V neurons in mouse cortex projecting to different targets have distinct physiological properties. J Neurophysiol 98:3330-3340. CrossRef Medline

Heuermann RJ, Jaramillo TC, Ying SW, Suter BA, Lyman KA, Han Y, Lewis AS, Hampton TG, Shepherd GM, Goldstein PA, Chetkovich DM (2016) Reduction of thalamic and cortical Ih by deletion of TRIP8b produces a mouse model of human absence epilepsy. Neurobiol Dis 85:81-92. CrossRef Medline

Hevner RF (2007) Layer-specific markers as probes for neuron type identity in human neocortex and malformations of cortical development. J Neuropathol Exp Neurol 66:101-109. CrossRef Medline

Hevner RF, Shi L, Justice N, Hsueh Y, Sheng M, Smiga S, Bulfone A, Goffinet AM, Campagnoni AT, Rubenstein JL (2001) Tbrl regulates differentiation of the preplate and layer 6. Neuron 29:353-366. CrossRef Medline

Hilscher MM, Leão RN, Edwards SJ, Leão KE, Kullander K (2017) Chrna2Martinotti cells synchronize layer 5 type A pyramidal cells via rebound excitation. Plos Biol 15:e2001392. CrossRef Medline

Hirai Y, Morishima M, Karube F, Kawaguchi Y (2012) Specialized cortical subnetworks differentially connect frontal cortex to parahippocampal areas. J Neurosci 32:1898-1913. CrossRef Medline

Hoerder-Suabedissen A, Hayashi S, Upton L, Nolan Z, Casas-Torremocha D, Grant E, Viswanathan S, Kanold PO, Clascá F, Kim Y, Molnár Z (2018) Subset of cortical layer $6 \mathrm{~b}$ neurons selectively innervates higher order thalamic nuclei in mice. Cereb Cortex 28:1882-1897. CrossRef Medline

Hooks BM, Hires SA, Zhang YX, Huber D, Petreanu L, Svoboda K, Shepherd GM (2011) Laminar analysis of excitatory local circuits in vibrissal motor and sensory cortical areas. Plos Biol 9:e1000572. CrossRef Medline

Hooks BM, Mao T, Gutnisky DA, Yamawaki N, Svoboda K, Shepherd GM (2013) Organization of cortical and thalamic input to pyramidal neurons in mouse motor cortex. J Neurosci 33:748-760. CrossRef Medline

Ito M (1992) Simultaneous visualization of cortical barrels and horseradish peroxidase-injected layer $5 \mathrm{~b}$ vibrissa neurones in the rat. J Physiol 454: 247-265. CrossRef Medline

Jara JH, Villa SR, Khan NA, Bohn MC, Özdinler PH (2012) AAV2 mediated retrograde transduction of corticospinal motor neurons reveals initial and selective apical dendrite degeneration in ALS. Neurobiol Dis 47:174183. CrossRef Medline

Joshi A, Middleton JW, Anderson CT, Borges K, Suter BA, Shepherd GM, Tzounopoulos T (2015) Cell-specific activity-dependent fractionation of layer $2 / 3 \rightarrow 5 \mathrm{~B}$ excitatory signaling in mouse auditory cortex. J Neurosci 35:3112-3123. CrossRef Medline

Kalmbach BE, Chitwood RA, Dembrow NC, Johnston D (2013) Dendritic generation of mGluR-mediated slow afterdepolarization in layer 5 neurons of prefrontal cortex. J Neurosci 33:13518-13532. CrossRef Medline

Kalmbach BE, Johnston D, Brager DH (2015) Cell type-specific channelopathies in the prefrontal cortex of the fmr1-/y mouse model of Fragile X syndrome. eNeuro 2:ENEURO.0114-15.2015. CrossRef Medline

Kalmbach BE, Gray R, Johnston D, Cook EP (2017) Systems-based analysis of dendritic nonlinearities reveals temporal feature extraction in mouse L5 cortical neurons. J Neurophysiol 117:2188-2208. CrossRef Medline

Katz LC (1987) Local circuitry of identified projection neurons in cat visual cortex brain slices. J Neurosci 7:1223-1249. CrossRef Medline

Kawaguchi A, Ikawa T, Kasukawa T, Ueda HR, Kurimoto K, Saitou M, Matsuzaki F (2008) Single-cell gene profiling defines differential progenitor subclasses in mammalian neurogenesis. Development 135:3113-3124. CrossRef Medline

Kawaguchi Y (2017) Pyramidal cell subtypes and their synaptic connections in layer 5 of rat frontal cortex. Cereb Cortex 27:5755-5771. CrossRef Medline

Kawaguchi Y, Kubota Y (1997) GABAergic cell subtypes and their synaptic connections in rat frontal cortex. Cereb Cortex 7:476-486. CrossRef Medline

Kawaguchi Y, Kubota Y (1998) Neurochemical features and synaptic connections of large physiologically-identified GABAergic cells in the rat frontal cortex. Neuroscience 85:677-701. CrossRef Medline

Kebschull JM, Garcia da Silva P, Reid AP, Peikon ID, Albeanu DF, Zador AM (2016) High-throughput mapping of single-neuron projections by sequencing of barcoded RNA. Neuron 91:975-987. CrossRef Medline

Kepecs A, Fishell G (2014) Interneuron cell types are fit to function. Nature 505:318-326. CrossRef Medline

Killackey HP, Sherman SM (2003) Corticothalamic projections from the rat primary somatosensory cortex. J Neurosci 23:7381-7384. CrossRef Medline

Kim CK, Ye L, Jennings JH, Pichamoorthy N, Tang DD, Yoo AW, Ramakrishnan C, Deisseroth K (2017) Molecular and circuit-dynamical identification of top-down neural mechanisms for restraint of reward seeking. Cell 170:1013-1027.e14. CrossRef Medline

Kim EJ, Juavinett AL, Kyubwa EM, Jacobs MW, Callaway EM (2015) Three types of cortical layer 5 neurons that differ in brain-wide connectivity and function. Neuron 88:1253-1267. CrossRef Medline

Kim J, Matney CJ, Blankenship A, Hestrin S, Brown SP (2014) Layer 6 corticothalamic neurons activate a cortical output layer, layer 5 a. J Neurosci 34:9656-9664. CrossRef Medline

Kim J, Hughes EG, Shetty AS, Arlotta P, Goff LA, Bergles DE, Brown SP (2017) Changes in the excitability of neocortical neurons in a mouse model of amyotrophic lateral sclerosis are not specific to corticospinal neurons and are modulated by advancing disease. J Neurosci 37:90379053. CrossRef Medline

Kinnischtzke AK, Fanselow EE, Simons DJ (2016) Target-specific M1 inputs to infragranular S1 pyramidal neurons. J Neurophysiol 116:12611274. CrossRef Medline

Kiritani T, Wickersham IR, Seung HS, Shepherd GM (2012) Hierarchical connectivity and connection-specific dynamics in the corticospinalcorticostriatal microcircuit in mouse motor cortex. J Neurosci 32:49925001. CrossRef Medline

Kita T, Kita H (2012) The subthalamic nucleus is one of multiple innervation sites for long-range corticofugal axons: a single-axon tracing study in the rat. J Neurosci 32:5990-5999. CrossRef Medline

Kole MH (2011) First node of Ranvier facilitates high-frequency burst encoding. Neuron 71:671-682. CrossRef Medline

Kole MH, Hallermann S, Stuart GJ (2006) Single Ih channels in pyramidal neuron dendrites: properties, distribution, and impact on action potential output. J Neurosci 26:1677-1687. CrossRef Medline

Kowalczyk T, Pontious A, Englund C, Daza RA, Bedogni F, Hodge R, Attardo A, Bell C, Huttner WB, Hevner RF (2009) Intermediate neuronal progenitors (basal progenitors) produce pyramidal-projection neurons for all layers of cerebral cortex. Cereb Cortex 19:2439-2450. CrossRef Medline

Kozloski J, Hamzei-Sichani F, Yuste R (2001) Stereotyped position of local synaptic targets in neocortex. Science 293:868-872. CrossRef Medline

Kubota K, Hamada I (1979) Preparatory activity of monkey pyramidal tract neurons related to quick movement onset during visual tracking performance. Brain Res 168:435-439. CrossRef Medline

Kubota Y, Hatada S, Kondo S, Karube F, Kawaguchi Y (2007) Neocortical inhibitory terminals innervate dendritic spines targeted by thalamocortical afferents. J Neurosci 27:1139-1150. CrossRef Medline

Kubota Y, Kondo S, Nomura M, Hatada S, Yamaguchi N, Mohamed AA, Karube F, Lübke J, Kawaguchi Y (2015) Functional effects of distinct innervation styles of pyramidal cells by fast spiking cortical interneurons. Elife 4:2015. CrossRef Medline

Kumar P, Ohana O (2008) Inter- and intralaminar subcircuits of excitatory and inhibitory neurons in layer $6 \mathrm{a}$ of the rat barrel cortex. J Neurophysiol 100:1909-1922. CrossRef Medline

Lai T, Jabaudon D, Molyneaux BJ, Azim E, Arlotta P, Menezes JR, Macklis JD (2008) SOX5 controls the sequential generation of distinct corticofugal neuron subtypes. Neuron 57:232-247. CrossRef Medline

Le Bé JV, Silberberg G, Wang Y, Markram H (2007) Morphological, electrophysiological, and synaptic properties of corticocallosal pyramidal cells in the neonatal rat neocortex. Cereb Cortex 17:2204-2213. CrossRef Medline

Ledergerber D, Larkum ME (2010) Properties of layer 6 pyramidal neuron apical dendrites. J Neurosci 30:13031-13044. CrossRef Medline 
Lee AT, Gee SM, Vogt D, Patel T, Rubenstein JL, Sohal VS (2014) Pyramidal neurons in prefrontal cortex receive subtype-specific forms of excitation and inhibition. Neuron 81:61-68. CrossRef Medline

Lefort S, Tomm C, Floyd Sarria JC, Petersen CC (2009) The excitatory neuronal network of the $\mathrm{C} 2$ barrel column in mouse primary somatosensory cortex. Neuron 61:301-316. CrossRef Medline

Leid M, Ishmael JE, Avram D, Shepherd D, Fraulob V, Dollé P (2004) CTIP1 and CTIP2 are differentially expressed during mouse embryogenesis. Gene Expr Patterns 4:733-739. CrossRef Medline

Leone DP, Srinivasan K, Chen B, Alcamo E, McConnell SK (2008) The determination of projection neuron identity in the developing cerebral cortex. Curr Opin Neurobiol 18:28-35. CrossRef Medline

Leone DP, Heavner WE, Ferenczi EA, Dobreva G, Huguenard JR, Grosschedl R, McConnell SK (2015) Satb2 regulates the differentiation of both callosal and subcerebral projection neurons in the developing cerebral cortex. Cereb Cortex 25:3406-3419. CrossRef Medline

Lévesque M, Gagnon S, Parent A, Deschênes M (1996) Axonal arborizations of corticostriatal and corticothalamic fibers arising from the second somatosensory area in the rat. Cereb Cortex 6:759-770. CrossRef Medline

Li B, Chen F, Ye J, Chen X, Yan J, Li Y, Xiong Y, Zhou Z, Xia J, Hu Z (2010) The modulation of orexin A on HCN currents of pyramidal neurons in mouse prelimbic cortex. Cereb Cortex 20:1756-1767. CrossRef Medline

Li CX, Waters RS (1991) Organization of the mouse motor cortex studied by retrograde tracing and intracortical microstimulation (ICMS) mapping. Can J Neurol Sci 18:28-38. CrossRef Medline

Li N, Chen TW, Guo ZV, Gerfen CR, Svoboda K (2015) A motor cortex circuit for motor planning and movement. Nature 519:51-56. CrossRef Medline

Li N, Daie K, Svoboda K, Druckmann S (2016) Robust neuronal dynamics in premotor cortex during motor planning. Nature 532:459-464. CrossRef Medline

Lodato S, Shetty AS, Arlotta P (2015) Cerebral cortex assembly: generating and reprogramming projection neuron diversity. Trends Neurosci 38: 117-125. CrossRef Medline

Lopes R, Korkmaz G, Agami R (2016) Applying CRISPR-Cas9 tools to identify and characterize transcriptional enhancers. Nat Rev Mol Cell Biol 17:597-604. CrossRef Medline

Lörincz A, Notomi T, Tamás G, Shigemoto R, Nusser Z (2002) Polarized and compartment-dependent distribution of HCN1 in pyramidal cell dendrites. Nat Neurosci 5:1185-1193. CrossRef Medline

Luo L, Callaway EM, Svoboda K (2018) Genetic dissection of neural circuits: a decade of progress. Neuron 98:256-281. CrossRef Medline

Lur G, Vinck MA, Tang L, Cardin JA, Higley MJ (2016) Projection-specific visual feature encoding by layer 5 cortical subnetworks. Cell Rep 14:25382545. CrossRef Medline

Magee JC (1998) Dendritic hyperpolarization-activated currents modify the integrative properties of hippocampal CAl pyramidal neurons. J Neurosci 18:7613-7624. CrossRef Medline

Maheshwari A, Noebels JL (2014) Monogenic models of absence epilepsy: windows into the complex balance between inhibition and excitation in thalamocortical microcircuits. Prog Brain Res 213:223-252. CrossRef Medline

Mallet N, Ballion B, Le Moine C, Gonon F (2006) Cortical inputs and GABA interneurons imbalance projection neurons in the striatum of parkinsonian rats. J Neurosci 26:3875-3884. CrossRef Medline

Manns ID, Sakmann B, Brecht M (2004) Sub- and suprathreshold receptive field properties of pyramidal neurones in layers $5 \mathrm{~A}$ and $5 \mathrm{~B}$ of rat somatosensory barrel cortex. J Physiol 556:601-622. CrossRef Medline

Mao T, Kusefoglu D, Hooks BM, Huber D, Petreanu L, Svoboda K (2011) Long-range neuronal circuits underlying the interaction between sensory and motor cortex. Neuron 72:111-123. CrossRef Medline

Markram H, Toledo-Rodriguez M, Wang Y, Gupta A, Silberberg G, Wu C (2004) Interneurons of the neocortical inhibitory system. Nat Rev Neurosci 5:793-807. CrossRef Medline

Marlin JJ, Carter AG (2014) GABA-A receptor inhibition of local calcium signaling in spines and dendrites. J Neurosci 34:15898-15911. CrossRef Medline

Maruoka H, Nakagawa N, Tsuruno S, Sakai S, Yoneda T, Hosoya T (2017) Lattice system of functionally distinct cell types in the neocortex. Science 358:610-615. CrossRef Medline

Mason A, Larkman A (1990) Correlations between morphology and elec- trophysiology of pyramidal neurons in slices of rat visual cortex: II. Electrophysiology. J Neurosci 10:1415-1428. CrossRef Medline

McConnell SK (1991) The generation of neuronal diversity in the central nervous system. Annu Rev Neurosci 14:269-300. CrossRef Medline

McCormick DA, Wang Z, Huguenard J (1993) Neurotransmitter control of neocortical neuronal activity and excitability. Cereb Cortex 3:387-398. CrossRef Medline

McKenna WL, Betancourt J, Larkin KA, Abrams B, Guo C, Rubenstein JL, Chen B (2011) Tbr1 and Fezf2 regulate alternate corticofugal neuronal identities during neocortical development. J Neurosci 31:549-564. CrossRef Medline

McKenna WL, Ortiz-Londono CF, Mathew TK, Hoang K, Katzman S, Chen B (2015) Mutual regulation between Satb2 and Fezf2 promotes subcerebral projection neuron identity in the developing cerebral cortex. Proc Natl Acad Sci U S A 112:11702-11707. CrossRef Medline

Mercer A, West DC, Morris OT, Kirchhecker S, Kerkhoff JE, Thomson AM (2005) Excitatory connections made by presynaptic cortico-cortical pyramidal cells in layer 6 of the neocortex. Cereb Cortex 15:1485-1496. CrossRef Medline

Miller MN, Okaty BW, Nelson SB (2008) Region-specific spike-frequency acceleration in layer 5 pyramidal neurons mediated by Kv1 subunits. J Neurosci 28:13716-13726. CrossRef Medline

Molnár Z, Cheung AF (2006) Towards the classification of subpopulations of layer V pyramidal projection neurons. Neurosci Res 55:105-115. CrossRef Medline

Molyneaux BJ, Arlotta P, Hirata T, Hibi M, Macklis JD (2005) Fezl is required for the birth and specification of corticospinal motor neurons. Neuron 47:817-831. CrossRef Medline

Molyneaux BJ, Arlotta P, Menezes JR, Macklis JD (2007) Neuronal subtype specification in the cerebral cortex. Nat Rev Neurosci 8:427-437. CrossRef Medline

Molyneaux BJ, Arlotta P, Fame RM, MacDonald JL, MacQuarrie KL, Macklis JD (2009) Novel subtype-specific genes identify distinct subpopulations of callosal projection neurons. J Neurosci 29:12343-12354. CrossRef Medline

Morishima M, Kawaguchi Y (2006) Recurrent connection patterns of corticostriatal pyramidal cells in frontal cortex. J Neurosci 26:4394-4405. CrossRef Medline

Morishima M, Morita K, Kubota Y, Kawaguchi Y (2011) Highly differentiated projection-specific cortical subnetworks. J Neurosci 31:1038010391. CrossRef Medline

Morishima M, Kobayashi K, Kato S, Kobayashi K, Kawaguchi Y (2017) Segregated excitatory-inhibitory recurrent subnetworks in layer 5 of the rat frontal cortex. Cereb Cortex 27:5846-5857. CrossRef Medline

Morrill RJ, Hasenstaub AR (2018) Visual information present in infragranular layers of mouse auditory cortex. J Neurosci 38:2854-2862. CrossRef Medline

Muralidharan B, Khatri Z, Maheshwari U, Gupta R, Roy B, Pradhan SJ, Karmodiya K, Padmanabhan H, Shetty AS, Balaji C, Kolthur-Seetharam U, Macklis JD, Galande S, Tole S (2017) LHX2 interacts with the NuRD complex and regulates cortical neuron subtype determinants Fezf2 and Sox11. J Neurosci 37:194-203. CrossRef Medline

Murphy PC, Duckett SG, Sillito AM (2000) Comparison of the laminar distribution of input from areas 17 and 18 of the visual cortex to the lateral geniculate nucleus of the cat. J Neurosci 20:845-853. CrossRef Medline

Naka A, Adesnik H (2016) Inhibitory circuits in cortical layer 5. Front Neural Circuits 10:35. CrossRef Medline

Narayanan RT, Udvary D, Oberlaender M (2017) Cell type-specific structural organization of the six layers in rat barrel cortex. Front Neuroanat 11:91. CrossRef Medline

Nudo RJ, Masterton RB (1990) Descending pathways to the spinal cord: III. Sites of origin of the corticospinal tract. J Comp Neurol 296:559-583. CrossRef Medline

Oberlaender M, de Kock CP, Bruno RM, Ramirez A, Meyer HS, Dercksen VJ, Helmstaedter M, Sakmann B (2012) Cell type-specific three-dimensional structure of thalamocortical circuits in a column of rat vibrissal cortex. Cereb Cortex 22:2375-2391. CrossRef Medline

Olsen SR, Bortone DS, Adesnik H, Scanziani M (2012) Gain control by layer six in cortical circuits of vision. Nature 483:47-52. CrossRef Medline

Oswald MJ, Tantirigama ML, Sonntag I, Hughes SM, Empson RM (2013) Diversity of layer 5 projection neurons in the mouse motor cortex. Front Cell Neurosci 7:174. CrossRef Medline 
Otsuka T, Kawaguchi Y (2008) Firing-pattern-dependent specificity of cortical excitatory feed-forward subnetworks. J Neurosci 28:11186-11195. CrossRef Medline

Otsuka T, Kawaguchi Y (2011) Cell diversity and connection specificity between callosal projection neurons in the frontal cortex. J Neurosci 31 : 3862-3870. CrossRef Medline

Özdinler PH, Benn S, Yamamoto TH, Güzel M, Brown RH Jr, Macklis JD (2011) Corticospinal motor neurons and related subcerebral projection neurons undergo early and specific neurodegeneration in hSOD $1 \mathrm{G}^{93} \mathrm{~A}$ transgenic ALS mice. J Neurosci 31:4166-4177. CrossRef Medline

Pasquereau B, Turner RS (2011) Primary motor cortex of the parkinsonian monkey: differential effects on the spontaneous activity of pyramidal tract-type neurons. Cereb Cortex 21:1362-1378. CrossRef Medline

Pasquereau B, Turner RS (2013) Primary motor cortex of the parkinsonian monkey: altered neuronal responses to muscle stretch. Front Syst Neurosci 7:98. CrossRef Medline

Pasquereau B, DeLong MR, Turner RS (2016) Primary motor cortex of the parkinsonian monkey: altered encoding of active movement. Brain 139: 127-143. CrossRef Medline

Pathak D, Guan D, Foehring RC (2016) Roles of specific Kv channel types in repolarization of the action potential in genetically identified subclasses of pyramidal neurons in mouse neocortex. J Neurophysiol 115:2317-2329. CrossRef Medline

Peters AJ, Lee J, Hedrick NG, O'Neil K, Komiyama T (2017) Reorganization of corticospinal output during motor learning. Nat Neurosci 20:11331141. CrossRef Medline

Petreanu L, Mao T, Sternson SM, Svoboda K (2009) The subcellular organization of neocortical excitatory connections. Nature 457:1142-1145. CrossRef Medline

Porrero C, Rubio-Garrido P, Avendaño C, Clascá F (2010) Mapping of fluorescent protein-expressing neurons and axon pathways in adult and developing Thy1-eYFP-H transgenic mice. Brain Res 1345:59-72. CrossRef Medline

Pouille F, Watkinson O, Scanziani M, Trevelyan AJ (2013) The contribution of synaptic location to inhibitory gain control in pyramidal cells. Physiol Rep 1:e00067. CrossRef Medline

Puig MV, Gulledge AT, Lambe EK, Gonzalez-Burgos G (2015) Editorial: neuromodulation of executive circuits. Front Neural Circuits 9:58. CrossRef Medline

Radnikow G, Feldmeyer D (2018) Layer- and cell type-specific modulation of excitatory neuronal activity in the neocortex. Front Neuroanat 12:1. CrossRef Medline

Rakic P (1974) Neurons in rhesus monkey visual cortex: systematic relation between time of origin and eventual disposition. Science 183:425-427. CrossRef Medline

Ramaswamy S, Markram H (2015) Anatomy and physiology of the thicktufted layer 5 pyramidal neuron. Front Cell Neurosci 9:233. CrossRef Medline

Reiner A, Jiao Y, Del Mar N, Laverghetta AV, Lei WL (2003) Differential morphology of pyramidal tract-type and intratelencephalically projecting-type corticostriatal neurons and their intrastriatal terminals in rats. J Comp Neurol 457:420-440. CrossRef Medline

Reyes A, Luján R, Rozov A, Burnashev N, Somogyi P, Sakmann B (1998) Target-cell-specific facilitation and depression in neocortical circuits. Nat Neurosci 1:279-285. CrossRef Medline

Rock C, Apicella AJ (2015) Callosal projections drive neuronal-specific responses in the mouse auditory cortex. J Neurosci 35:6703-6713. CrossRef Medline

Rojas-Piloni G, Guest JM, Egger R, Johnson AS, Sakmann B, Oberlaender M (2017) Relationships between structure, in vivo function and long-range axonal target of cortical pyramidal tract neurons. Nat Commun 8:870. CrossRef Medline

Rosen DR, Siddique T, Patterson D, Figlewicz DA, Sapp P, Hentati A, Donaldson D, Goto J, O'Regan JP, Deng HX (1993) Mutations in Cu/Zn superoxide dismutase gene are associated with familial amyotrophic lateral sclerosis. Nature 362:59-62. CrossRef Medline

Rosenberg AB, Roco CM, Muscat RA, Kuchina A, Sample P, Yao Z, Graybuck LT, Peeler DJ, Mukherjee S, Chen W, Pun SH, Sellers DL, Tasic B, Seelig G (2018) Single-cell profiling of the developing mouse brain and spinal cord with split-pool barcoding. Science 360:176-182. CrossRef Medline

Rouiller EM, Moret V, Liang F (1993) Comparison of the connectional properties of the two forelimb areas of the rat sensorimotor cortex: sup- port for the presence of a premotor or supplementary motor cortical area. Somatosens Mot Res 10:269-289. CrossRef Medline

Rudy B, Fishell G, Lee S, Hjerling-Leffler J (2011) Three groups of interneurons account for nearly $100 \%$ of neocortical GABAergic neurons. Dev Neurobiol 71:45-61. CrossRef Medline

Saba L, Viscomi MT, Caioli S, Pignataro A, Bisicchia E, Pieri M, Molinari M, Ammassari-Teule M, Zona C (2016) Altered functionality, morphology, and vesicular glutamate transporter expression of cortical motor neurons from a presymptomatic mouse model of amyotrophic lateral sclerosis. Cereb Cortex 26:1512-1528. CrossRef Medline

Saiki A, Sakai Y, Fukabori R, Soma S, Yoshida J, Kawabata M, Yawo H, Kobayashi K, Kimura M, Isomura Y (2018) In vivo spiking dynamics of intra- and extratelencephalic projection neurons in rat motor cortex. Cereb Cortex 28:1024-1038. CrossRef Medline

Schneider DM, Nelson A, Mooney R (2014) A synaptic and circuit basis for corollary discharge in the auditory cortex. Nature 513:189-194. CrossRef Medline

Schmidt EF, Warner-Schmidt JL, Otopalik BG, Pickett SB, Greengard P, Heintz N (2012) Identification of the cortical neurons that mediate antidepressant responses. Cell 149:1152-1163. CrossRef Medline

Seeley WW, Merkle FT, Gaus SE, Craig AD, Allman JM, Hof PR (2012) Distinctive neurons of the anterior cingulate and frontoinsular cortex: a historical perspective. Cereb Cortex 22:245-250. CrossRef Medline

Sheets PL, Shepherd GM (2011) Cortical circuits for motor control. Neuropsychopharmacology 36:365-366. CrossRef Medline

Sheets PL, Suter BA, Kiritani T, Chan CS, Surmeier DJ, Shepherd GM (2011) Corticospinal-specific HCN expression in mouse motor cortex: $\mathrm{I}(\mathrm{h})$ dependent synaptic integration as a candidate microcircuit mechanism involved in motor control. J Neurophysiol 106:2216-2231. CrossRef Medline

Shenoy KV, Sahani M, Churchland MM (2013) Cortical control of arm movements: a dynamical systems perspective. Annu Rev Neurosci 36: 337-359. CrossRef Medline

Shepherd GM (2009) Intracortical cartography in an agranular area. Front Neurosci 3:337-343. CrossRef Medline

Shepherd GM (2013) Corticostriatal connectivity and its role in disease. Nat Rev Neurosci 14:278-291. CrossRef Medline

Shima Y, Sugino K, Hempel CM, Shima M, Taneja P, Bullis JB, Mehta S, Lois C, Nelson SB (2016) A mammalian enhancer trap resource for discovering and manipulating neuronal cell types. Elife 5:e13503. CrossRef Medline

Shipp S, Adams RA, Friston KJ (2013) Reflections on agranular architecture: predictive coding in the motor cortex. Trends Neurosci 36:706-716. CrossRef Medline

Sirota MG, Swadlow HA, Beloozerova IN (2005) Three channels of corticothalamic communication during locomotion. J Neurosci 25:5915-5925. CrossRef Medline

Soma S, Saiki A, Yoshida J, Ríos A, Kawabata M, Sakai Y, Isomura Y (2017) Distinct laterality in forelimb-movement representations of rat primary and secondary motor cortical neurons with intratelencephalic and pyramidal tract projections. J Neurosci 37:10904-10916. CrossRef Medline

Sorensen SA, Bernard A, Menon V, Royall JJ, Glattfelder KJ, Desta T, Hirokawa K, Mortrud M, Miller JA, Zeng H, Hohmann JG, Jones AR, Lein ES (2015) Correlated gene expression and target specificity demonstrate excitatory projection neuron diversity. Cereb Cortex 25:433-449. CrossRef Medline

Spain WJ, Schwindt PC, Crill WE (1991) Post-inhibitory excitation and inhibition in layer V pyramidal neurones from cat sensorimotor cortex. J Physiol 434:609-626. CrossRef Medline

Sparks DW, Tian MK, Sargin D, Venkatesan S, Intson K, Lambe EK (2017) Opposing cholinergic and serotonergic modulation of layer 6 in prefrontal cortex. Front Neural Circuits 11:107. CrossRef Medline

Srinivasan K, Leone DP, Bateson RK, Dobreva G, Kohwi Y, KohwiShigematsu T, Grosschedl R, McConnell SK (2012) A network of genetic repression and derepression specifies projection fates in the developing neocortex. Proc Natl Acad Sci U S A 109:19071-19078. CrossRef Medline

Sugino K, Hempel CM, Miller MN, Hattox AM, Shapiro P, Wu C, Huang ZJ, Nelson SB (2006) Molecular taxonomy of major neuronal classes in the adult mouse forebrain. Nat Neurosci 9:99-107. CrossRef Medline

Sundberg SC, Lindström SH, Sanchez GM, Granseth B (2018) Creexpressing neurons in visual cortex of Ntsr1-cre GN220 mice are cortico- 
thalamic and are depolarized by acetylcholine. J Comp Neurol 526:120132. CrossRef Medline

Suter BA, Shepherd GM (2015) Reciprocal interareal connections to corticospinal neurons in mouse $\mathrm{ml}$ and s2. J Neurosci 35:2959-2974. CrossRef Medline

Suter BA, Migliore M, Shepherd GM (2013) Intrinsic electrophysiology of mouse corticospinal neurons: a class-specific triad of spike-related properties. Cereb Cortex 23:1965-1977. CrossRef Medline

Svoboda K, Li N (2018) Neural mechanisms of movement planning: motor cortex and beyond. Curr Opin Neurobiol 49:33-41. CrossRef Medline

Swadlow HA (1989) Efferent neurons and suspected interneurons in S-1 vibrissa cortex of the awake rabbit: receptive fields and axonal properties. J Neurophysiol 62:288-308. CrossRef Medline

Taniguchi H (2014) Genetic dissection of GABAergic neural circuits in mouse neocortex. Front Cell Neurosci 8:8. CrossRef Medline

Tanji J, Evarts EV (1976) Anticipatory activity of motor cortex neurons in relation to direction of an intended movement. J Neurophysiol 39:10621068. CrossRef Medline

Tantirigama ML, Oswald MJ, Duynstee C, Hughes SM, Empson RM (2014) Expression of the developmental transcription factor Fezf2 identifies a distinct subpopulation of layer 5 intratelencephalic-projection neurons in mature mouse motor cortex. J Neurosci 34:4303-4308. CrossRef Medline

Tantirigama ML, Oswald MJ, Clare AJ, Wicky HE, Day RC, Hughes SM, Empson RM (2016) Fezf2 expression in layer 5 projection neurons of mature mouse motor cortex. J Comp Neurol 524:829-845. CrossRef Medline

Tasic B, Menon V, Nguyen TN, Kim TK, Jarsky T, Yao Z, Levi B, Gray LT, Sorensen SA, Dolbeare T, Bertagnolli D, Goldy J, Shapovalova N, Parry S, Lee C, Smith K, Bernard A, Madisen L, Sunkin SM, Hawrylycz M, et al. (2016) Adult mouse cortical cell taxonomy revealed by single cell transcriptomics. Nat Neurosci 19:335-346. CrossRef Medline

Tervo DG, Hwang BY, Viswanathan S, Gaj T, Lavzin M, Ritola KD, Lindo S, Michael S, Kuleshova E, Ojala D, Huang CC, Gerfen CR, Schiller J, Dudman JT, Hantman AW, Looger LL, Schaffer DV, Karpova AY (2016) A designer AAV variant permits efficient retrograde access to projection neurons. Neuron 92:372-382. CrossRef Medline

Thomson AM (2010) Neocortical layer 6, a review. Front Neuroanat 4:13. CrossRef Medline

Thomson AM, Lamy C (2007) Functional maps of neocortical local circuitry. Front Neurosci 1:19-42. CrossRef Medline

Tremblay R, Lee S, Rudy B (2016) GABAergic interneurons in the neocortex: from cellular properties to circuits. Neuron 91:260-292. CrossRef Medline

Turner RS, DeLong MR (2000) Corticostriatal activity in primary motor cortex of the macaque. J Neurosci 20:7096-7108. CrossRef Medline

Ueta Y, Hirai Y, Otsuka T, Kawaguchi Y (2013) Direction- and distancedependent interareal connectivity of pyramidal cell subpopulations in the rat frontal cortex. Front Neural Circuits 7:164. CrossRef Medline

Ueta Y, Otsuka T, Morishima M, Ushimaru M, Kawaguchi Y (2014) Multiple layer 5 pyramidal cell subtypes relay cortical feedback from secondary to primary motor areas in rats. Cereb Cortex 24:2362-2376. CrossRef Medline

Ushimaru M, Kawaguchi Y (2015) Temporal structure of neuronal activity among cortical neuron subtypes during slow oscillations in anesthetized rats. J Neurosci 35:11988-12001. CrossRef Medline

Usrey WM, Fitzpatrick D (1996) Specificity in the axonal connections of layer VI neurons in tree shrew striate cortex: evidence for distinct granular and supragranular systems. J Neurosci 16:1203-1218. CrossRef Medline

Vaidya SP, Johnston D (2013) Temporal synchrony and gamma-to-theta power conversion in the dendrites of CA1 pyramidal neurons. Nat Neurosci 16:1812-1820. CrossRef Medline

van Aerde KI, Qi G, Feldmeyer D (2015) Cell type-specific effects of adenosine on cortical neurons. Cereb Cortex 25:772-787. CrossRef Medline

Vasistha NA, García-Moreno F, Arora S, Cheung AF, Arnold SJ, Robertson EJ, Molnár Z (2015) Cortical and clonal contribution of Tbr2 expressing progenitors in the developing mouse brain. Cereb Cortex 25:3290-3302. CrossRef Medline

Vélez-Fort M, Rousseau CV, Niedworok CJ, Wickersham IR, Rancz EA, Brown AP, Strom M, Margrie TW (2014) The stimulus selectivity and connectivity of layer six principal cells reveals cortical microcircuits underlying visual processing. Neuron 84:238. CrossRef Medline

Voelker CC, Garin N, Taylor JS, Gähwiler BH, Hornung JP, Molnár Z (2004)
Selective neurofilament (SMI-32, FNP-7 and N200) expression in subpopulations of layer $\mathrm{V}$ pyramidal neurons in vivo and in vitro. Cereb Cortex 14:1276-1286. CrossRef Medline

von Economo CF, Koskinas GN (2007) Atlas of cytoarchitectonics of the adult human cerebral cortex. Basel: Karger.

Wang W, Jones HE, Andolina IM, Salt TE, Sillito AM (2006) Functional alignment of feedback effects from visual cortex to thalamus. Nat Neurosci 9:1330-1336. CrossRef Medline

Wang W, Andolina IM, Lu Y, Jones HE, Sillito AM (2018) Focal gain control of thalamic visual receptive fields by layer 6 corticothalamic feedback. Cereb Cortex 28:267-280. CrossRef Medline

Wang Y, Markram H, Goodman PH, Berger TK, Ma J, Goldman-Rakic PS (2006) Heterogeneity in the pyramidal network of the medial prefrontal cortex. Nat Neurosci 9:534-542. CrossRef Medline

Wang Z, McCormick DA (1993) Control of firing mode of corticotectal and corticopontine layer $\mathrm{V}$ burst-generating neurons by norepinephrine, acetylcholine, and 1S,3R-ACPD. J Neurosci 13:2199-2216. CrossRef Medline

Warden MR, Selimbeyoglu A, Mirzabekov JJ, Lo M, Thompson KR, Kim SY, Adhikari A, Tye KM, Frank LM, Deisseroth K (2012) A prefrontal cortex-brainstem neuronal projection that controls response to behavioural challenge. Nature 492:428-432. CrossRef Medline

West DC, Mercer A, Kirchhecker S, Morris OT, Thomson AM (2006) Layer 6 cortico-thalamic pyramidal cells preferentially innervate interneurons and generate facilitating EPSPs. Cereb Cortex 16:200-211. CrossRef Medline

Williams SR, Stuart GJ (2000) Site independence of EPSP time course is mediated by dendritic $\mathrm{I}(\mathrm{h})$ in neocortical pyramidal neurons. J Neurophysiol 83:3177-3182. CrossRef Medline

Wilson CJ (1987) Morphology and synaptic connections of crossed corticostriatal neurons in the rat. J Comp Neurol 263:567-580. CrossRef Medline

Wise SP, Jones EG (1977) Cells of origin and terminal distribution of descending projections of the rat somatic sensory cortex. J Comp Neurol 175:129-157. CrossRef Medline

Xiong Q, Znamenskiy P, Zador AM (2015) Selective corticostriatal plasticity during acquisition of an auditory discrimination task. Nature 521: 348-351. CrossRef Medline

Ye Z, Mostajo-Radji MA, Brown JR, Rouaux C, Tomassy GS, Hensch TK, Arlotta P (2015) Instructing perisomatic inhibition by direct lineage reprogramming of neocortical projection neurons. Neuron 88:475-483. CrossRef Medline

Yoneshima H, Yamasaki S, Voelker CC, Molnár Z, Christophe E, Audinat E, Takemoto M, Nishiwaki M, Tsuji S, Fujita I, Yamamoto N (2006) Er81 is expressed in a subpopulation of layer 5 neurons in rodent and primate neocortices. Neuroscience 137:401-412. CrossRef Medline

Zeisel A, Muñoz-Manchado AB, Codeluppi S, Lönnerberg P, La Manno G, Juréus A, Marques S, Munguba H, He L, Betsholtz C, Rolny C, CasteloBranco G, Hjerling-Leffler J, Linnarsson S (2015) Brain structure: cell types in the mouse cortex and hippocampus revealed by single-cell RNAseq. Science 347:1138-1142. CrossRef Medline

Zeng H, Shen EH, Hohmann JG, Oh SW, Bernard A, Royall JJ, Glattfelder KJ, Sunkin SM, Morris JA, Guillozet-Bongaarts AL, Smith KA, Ebbert AJ, Swanson B, Kuan L, Page DT, Overly CC, Lein ES, Hawrylycz MJ, Hof PR, Hyde TM, et al. (2012) Large-scale cellular-resolution gene profiling in human neocortex reveals species-specific molecular signatures. Cell 149: 483-496. CrossRef Medline

Zhang GX, Sasamoto K (1990) Projections of two separate cortical areas for rhythmical jaw movements in the rat. Brain Res Bull 24:221-230. CrossRef Medline

Zhang Y, Bonnan A, Bony G, Ferezou I, Pietropaolo S, Ginger M, Sans N, Rossier J, Oostra B, LeMasson G, Frick A (2014) Dendritic channelopathies contribute to neocortical and sensory hyperexcitability in Fmr1(-/y) mice. Nat Neurosci 17:1701-1709. CrossRef Medline

Zhang ZW, Deschênes M (1997) Intracortical axonal projections of lamina VI cells of the primary somatosensory cortex in the rat: a single-cell labeling study. J Neurosci 17:6365-6379. CrossRef Medline

Znamenskiy P, Zador AM (2013) Corticostriatal neurons in auditory cortex drive decisions during auditory discrimination. Nature 497:482-485. CrossRef Medline

Zurita H, Rock C, Perkins J, Apicella AJ (2017) A layer-specific corticofugal input to the mouse superior colliculus. Cereb Cortex 2017:1-17. CrossRef Medline 